Schulich School of Law, Dalhousie University

Schulich Law Scholars

Articles, Book Chapters, \& Blogs

Faculty Scholarship

2016

\title{
Ocean Law Reform: A Multi-Level Comparative Law Analysis of Nigerian Maritime Zone Legislation
}

\author{
Aldo Chircop \\ Dalhousie University Schulich School of Law, aldo.chircop@dal.ca \\ David Dzidzornu \\ Dalhousie University Schulich School of Law, davidzid@dal.ca \\ Chidi Oguamanam \\ University of Ottawa, Chidi.Oguamanam@uottawa.ca
}

Follow this and additional works at: https://digitalcommons.schulichlaw.dal.ca/scholarly_works

Part of the Comparative and Foreign Law Commons, and the Environmental Law Commons

\section{Recommended Citation}

Aldo Chircop, David Dzidzornu \& Chidi Oguamanam, "Ocean Law Reform: A Multi-Level Comparative Law Analysis of Nigerian Maritime Zone Legislation" (2016) 67 Marine Policy 60.

This Article is brought to you for free and open access by the Faculty Scholarship at Schulich Law Scholars. It has been accepted for inclusion in Articles, Book Chapters, \& Blogs by an authorized administrator of Schulich Law Scholars. For more information, please contact hannah.steeves@dal.ca. 


\title{
[PRE-PUBLICATION VERSION: \\ THE FINAL VERSION OF THIS PAPER IS AVAILABLE AT: \\ 67 MARINE POLICY 60-75 (2016)]
}

\section{Ocean law reform: A multi-level comparative law analysis of Nigerian maritime zone legislation}

\begin{abstract}
Aldo Chircop
Professor of Law and Canada Research Chair in Maritime Law and Policy, Schulich School of Law, Dalhousie University, 6061 University Avenue, P.O. Box 15000, Halifax, Nova Scotia, B3H 4R2, Canada. Email: aldo.chircop@ dal.ca.

David Dzidzornu

Research Associate, Marine \& Environmental Law Institute, Schulich School of Law, Dalhousie University, 6061 University Avenue, P.O. Box 15000, Halifax, Nova Scotia, B3H 4R2, Canada. Email: davidzid@dal.ca.

Chidi Oguamanam

Associate Professor of Law, Centre for Law, Technology and Society, Faculty of Law (Common Law Section), University of Ottawa, Canada. Email: Chidi.Oguamanam@uottawa.ca.
\end{abstract}

\begin{abstract}
Recently, Nigeria introduced a Bill in the House and Senate that aims at modernizing its maritime zone legislation to enable it to maximize benefits it has received from the United Nations Convention on the Law of the Sea, 1982. Although Nigeria has been a party to the Convention for many years, the legislative initiative was triggered only recently by a mixture of events, including a submission to the Commission on the Limits of the Continental Shelf and the delimitation of maritime boundaries and adoption of joint development zones with neighbouring States, including the implementation of a judgment of the International Court of Justice. This article discusses how a comparative law approach to law reform was used by benchmarking Nigeria's legislative initiative against its treaty rights and obligations and the maritime legislation of selected States in
\end{abstract}


the region and elsewhere. The regional spread of the comparator jurisdictions is important, as are the impacts of national socio-economic circumstances and constitutional and political structure on the character and philosophy of legislative drafting and the prospects of its effective enforcement. The analysis identifies that the Nigerian reform stands to influence and encourage similar legislative changes among the East and West African regional seas littorals, thereby to likely enhance cooperative governance and regulation of ocean use in both regions.

\section{Key Terms}

comparative approach; Maritime Zones Act; Nigeria; ocean law reform; UN LOS Convention; West Africa

\section{Acknowledgements}

The authors acknowledge the kind consent of Seaforth Engineering Group Inc., Dartmouth, Nova Scotia, Canada, for use of parts of the Nigeria Maritime Boundary Legislation Delimitation Project report prepared by the authors for the Marine \& Environmental Law Institute, Schulich School of Law, Dalhousie University, Halifax, Nova Scotia, Canada, 30 November 2006. Professor Chircop also acknowledges the generous support of a grant from the Social Sciences Humanities Research Council of Canada to enable continuation of research on this article. 


\section{Introduction}

The Federal Republic of Nigeria (Nigeria) is a major beneficiary of the United Nations Convention on the Law of the Sea, 1982 (LOS Convention or the Convention) ${ }^{1}$. Nigeria signed the Convention on 10 December 1982 and ratified it on 14 August 1986. ${ }^{2}$ The Convention came into force on 16 November 1994. Under the Convention, Nigeria is entitled to a 12-nautical mile territorial sea, 24-nautical mile contiguous zone and an associated jurisdiction regarding archaeological and historical objects, 200-nautical mile exclusive economic zone (EEZ) and continental shelf which at a minimum is co-extensive with the EEZ and beyond to an outer limit of 350 nautical miles from coastal baselines or 100 nautical miles from the 2500 metre isobath. ${ }^{3}$ Despite its rights at international law, Nigeria did not take steps to fully maximize its jurisdictional entitlements until recently. This is remarkable because Nigeria ratified the LOS Convention for more than a quarter century and was an active negotiator during the Third United Nations Conference on the Law of the Sea 1973-1982. In addition to treaty entitlements, Nigeria has had other reasons to consolidate its LOS Convention gains, including growing offshore oil and gas activity, strong maritime trade, fisheries, maritime security concerns and marine environment protection from vessel-source pollution emanating from a major trade route through its EEZ.

The triggers for change appear to have been external and internal. Nigeria was a reluctant litigant in a case adjudicated by the International Court of Justice (ICJ), consequent to which it had to relinquish the Bakassi peninsula with its valuable coastal frontage to neighbouring Cameroon. ${ }^{4}$ The change in political geography has necessitated a domestic and bilateral process of rearrangement of terrestrial and maritime boundaries with its neighbour. ${ }^{5}$ Nigeria negotiated its maritime boundary with Benin, ${ }^{6}$ maritime boundary and joint exploration agreement with neighbouring Equatorial Guinea, ${ }^{7}$ and joint development zone with São Tomé e Príncipe. ${ }^{8}$ Perhaps the most far-reaching trigger to change in Nigerian ocean policy was the submission concerning 
the outer limits of its continental shelf to the Commission on the Limits of the Continental Shelf (CLCS or the Commission). ${ }^{9}$ The submission is currently under consideration by the CLCS ${ }^{10}$ and if successful, the continental shelf area over which Nigeria will be able to exercise sovereign rights for the purposes of exploring and exploiting its non-living natural resources will increase to some appreciable extent. ${ }^{11}$

The prospect of defining the extended continental shelf, while clearly a treaty right, has necessitated domestic legislative action to enable the exercise of ensuing sovereign rights and jurisdictions beyond those provided in current national legislation. That need prompted a review of existing legislation to ascertain the extent to which Nigeria has maximized benefits under the LOS Convention. Until recently, Nigeria had not taken steps to optimise its claims in the delineation of baselines, contiguous zone and jurisdiction for submarine archaeological and historical objects, some jurisdictions in the EEZ, and the definition of the outer limits of the extended continental shelf. In 2009, these needs culminated in a milestone initiative in the National Assembly of Nigeria aimed at overhauling the country's legislation claiming maritime zones and the exercise of related jurisdictions permitted by the international law of the sea, through House Bill 170 and Senate Bill 240 entitled 'A Bill for an Act to Repeal the Exclusive Economic Zone Act Cap. E17 LFN 2004 and the Territorial Waters Act Cap. TS LPN 2004 and Enact the Maritime Zones Act to Provide for the Maritime Zones of Nigeria and for Matters Connected Therewith' (House/Senate Bill or the Bill) ${ }^{12}$. At the time of writing, the Bill is awaiting consideration by the House and Senate, and following which it will be communicated for Presidential assent (signature) before it could come into force. The initiative was the result of preparatory work at the Ministry of Justice and Attorney-General's office, including supporting research as part of internal and external review processes. Focusing on the Nigerian experience, this article narrates how the 
comparative law approach was formulated and employed to guide research in support of public law reform in an ocean context.

The process leading to the House/Senate Bill, Nigeria's nascent Maritime Zones Act, is of interest to comparative law scholars and sea lawyers for several reasons. Because Nigeria is a dualist state, the LOS Convention could only become effective at the domestic level when implemented by legislation (i.e., adopted or transformed into domestic law). ${ }^{13}$ A major ocean legislative initiative by a leading African State can be expected to be observed and studied by other regional States, especially since a major purpose is the harmonization of national law of the sea legislation with international conventional law entitlements and obligations. Nigeria is in a position to play a significant leadership role in the law of the sea by modernizing its legislation in a manner to provide a model approach to maritime zone legislation and the legal administration of maritime zones in the region. It is an important State, located in West Africa's Gulf of Guinea where it occupies a geographically strategic position of neighbourliness with several other States. The process is also worthy of study because of the manner in which the comparative law approach was tailored and used to suit Nigeria's needs, its rights and obligations under international law, trends in national ocean legislation and the regional African context. The article commences with an explanation of the comparative approach and methodology developed for this study. A profile of Nigeria as a major regional coastal State and the context for the legislative initiative is set out. The article then proceeds to discuss the application of the comparative analytical approach by addressing some of the major aspects of the legislative initiative. The conclusion highlights lessons for comparative ocean law reform. 


\section{Context and Issues}

\subsection{The West African and Nigerian Context}

British colonial authorities officially established Nigeria as a single geo-political entity on 1 January 1914, barely over 100 years ago. The country resulted from the self-serving decision by the British to amalgamate its two separately administered Protectorates of Southern and Northern Nigeria. Diverse but vibrant historic African ethnic nationalities, kingdoms and civilizations constituted each of the Protectorates. These traditional African entities were sites of initial colonial contacts via transatlantic slave trading competitions among the Portuguese, the Dutch, the French and the British. The latter emerged as the dominant colonial power in the River Niger area and exercised its colonial authority in the two Protectorates over several decades before the 1914 amalgamation. Following amalgamation, the British sustained colonial authority over Nigeria for the next forty-six years before the country gained independence on 1 October $1960 .{ }^{14}$

At independence, Nigeria was the greatest British colonial outpost in the West African region. ${ }^{15}$ By its location on the Gulf of Guinea in West Africa, Nigeria shares land boundaries with Benin in the West $(773 \mathrm{~km})$, Cameroon in the East $(1,690 \mathrm{~km})$, Chad in the North East $(87 \mathrm{~km})$, and Niger in the North West $(1,497 \mathrm{~km})$. Nigeria occupies a total area of $923,768 \mathrm{sq} \mathrm{km}$, including a land and water area of 910,768 and 13,000 sq kms respectively, and a coastline of $835 \mathrm{kms}$. Its elevation extremes are, at the lowest point, zero metres (Atlantic Ocean), and at the highest point, 2,419 metres (Chappal Waddi). ${ }^{16}$ In addition to almost 40 per cent of arable land, rich biological diversity and unique ecological zones, Nigeria is also rich in resources like natural gas, petroleum, tin, iron ore, coal, limestone, niobium, lead and zinc. ${ }^{17}$

The fragility and strength of Nigeria as a British creation continues to be tested after independence. The tipping point of that experience was the $1967-70$ Nigerian civil war. ${ }^{18}$ 
Nigeria's success in the war forestalled the emergence of the breakaway Republic of Biafra. Despite resisting fragmentation, Nigeria's survival remains a continuous exercise in political brinkmanship. The civil war was provoked, in part, by a military coup d'état that sacked the immediate post-colonial civilian administration. ${ }^{19}$ In retrospect, it was also the foundation for the country's long-drawn experience with military dictatorships which followed the civil war and lasted until 1979, when Nigeria returned to civil rule under an American-style federal constitutional democracy with strong federal powers. ${ }^{20}$ Several years of military rule resulted in sometimes arbitrary or politically expedient 'creation' of subnational units or states to address an ever-present quest for autonomy by diverse peoples and ethnic and cultural entities that were cobbled together without a strong sense of national identity. Despite Nigeria's pretension to being a federation, for all practical purposes, the military ruled the country as a unitary state. Ironically, this bequeathed a federalist state with an unsurprisingly strong central government.

At the return of civil rule in 1979, Nigeria had 19 federating states and an envisaged federal Capital Territory in Abuja, which became officially functional in 1991, courtesy of a military regime. But civil rule was short-lived, as the military returned in 1983 to disrupt another constitutional order. ${ }^{21}$ An attempt to restore civilian rule was aborted in $1993 .{ }^{22}$ Consequently, it took the next 16 years (from 1983) for Nigeria to fully return to civil rule in 1999 through the inauguration of a new federal constitution authored by the military. Meanwhile its sub-national federating units have since mushroomed to 36 states, each with its own executive, legislative and judicial branches of government. ${ }^{23}$ The 1999 Constitution built upon the 1979 and the still-born 1993 constitutions to reaffirm Nigeria's status as a federal state and to set it on its path again as a constitutional democracy. The 1999 Constitution recognizes three tiers of government: federal, state and local, with devolution of powers enunciated under a broad legislative list. 
The 1999 Constitution entrenches multiple juridical and mixed legal systems drawing from common law, customary and Islamic legal traditions, with corresponding court systems established to exercise constitutionally delineated jurisdictions at federal, state and local government levels. Under an elaborate exclusive legislative list, the federal government has, among other things, sole legislative powers over the territorial integrity of the federation and matters dealing with maritime areas, shipping, navigation, mines and minerals including oil fields, oil mining, geological surveys, and natural gas. ${ }^{24}$ The federal high court has exclusive admiralty jurisdiction, including over shipping and navigation. ${ }^{25}$ There are two federal chambers of the legislature, the Senate and the House of Representatives, which constitute the National Assembly vested with powers to make laws on subject matters as spelt out in the Constitution pursuant to the exclusive and concurrent legislative lists.

So far, Nigeria has sustained an uninterrupted constitutional democracy, at the time of writing, for another 16 years from 1999, the longest such experience in its history. With a population of over 173 million people, Nigeria is Africa's most populous country and accounts for over half the total population of West Africa, as the combined total population of the rest of the region's fifteen countries is approximately 160 million. Like most other African countries, an overwhelming percentage of Nigeria's population is very young; in fact, currently, Africa is said to be the world's youngest continent. ${ }^{26}$ With its rich oil reserves, a growing entrepreneurial middle class, an economy that has been growing at seven per cent per annum for the past decade and an overall strong human potential, not many were surprised when, recently, Nigeria was ranked above South Africa as the largest economy in Africa, and its population is projected to be 440 million in 2050, above that of the United States at about 400 million. ${ }^{27}$ Nigeria's prospect to maintain economic growth and its status as an African regional power depends, in part, on stability in the 
West African region, Nigeria's ability to well manage its huge offshore and onshore oil reserves, and political cooperation among its subnational federating units. ${ }^{28}$ Thus far, Nigeria has been a stabilizing military and economic power in Africa, especially in the West African region through the Economic Community of West African States (ECOWAS). ${ }^{29}$

One of the highlights of the country's 1999 Constitution is the incorporation of derivation principles that guarantee the allocation of not less than 13 per cent of the revenue derived from natural resources to resource bearing states. ${ }^{30}$ This is Nigeria's response to the ever present struggle among the federating states for control over the country's natural resources, especially in relation to the oil-bearing Niger Delta region. It is not unusual for the states to challenge the authority or jurisdiction of the federal government regarding the allocation of revenue from on-shore and offshore oil exploration activities. ${ }^{31}$ In addition, like other African countries, national security also poses an increasingly complex challenge to Nigeria. Given these interrelated concerns, the Nigerian Maritime Zones legislation would assist to provide clarity on relevant gray areas under the Constitution; calibrate the country's maritime regime to the globally applicable principles and rules under the LOS Convention; and provide internal legal basis to avoid and/or settle conflicts between constituent states, and with the country's neighbours and, thus, avoid any more disputes similar to the one with Cameroon over the Bakassi Peninsula ${ }^{32}$ and elsewhere.

\subsection{Issues}

The process of preparing a CLCS submission involves complex scientific and technical work according to criteria in the LOS Convention and guidelines and procedures established by the Commission. ${ }^{33}$ As part of this exercise, it is necessary to consider how Nigerian domestic law supports extended continental shelf jurisdiction. Historically, as a party to the Geneva 
Conventions of $1958,{ }^{34}$ Nigeria claimed maritime zones permissible under those instruments through the Territorial Waters Act and Petroleum Act. ${ }^{35}$ Following the emergence of the EEZ as a concept of customary international law in the 1970s, Nigeria legislated the Exclusive Economic Zone Act. ${ }^{36}$ The definitions of the various maritime zones provided the necessary jurisdictional framework for the administration of several instruments concerned with sea use and public order.

Although by and large this legislative scheme served Nigeria's interests well until the early 1990s, it was clear that with the coming into force of the LOS Convention in 1994, Nigeria's ability to fully optimize benefits under that instrument was constrained. There were several issues. The first was that while Nigeria was entitled to an extended continental shelf under article 76 of the LOS Convention, the pertinent definition of the continental shelf was drawn from the Geneva Convention on the Continental Shelf 1958, and consisting of a formula based on isobath and exploitability. ${ }^{37}$ The LOS Convention superseded the 1958 conventions insofar as State parties are concerned. ${ }^{38}$ Second, Nigeria did not appear to maximize its full entitlements to maritime zones, including technical rules and procedures permissible under the LOS Convention. For example, although entitled to a contiguous zone under both the Convention on the Territorial Sea and Contiguous Zone 1958, and the LOS Convention, ${ }^{39}$ there was no provision for a contiguous zone in Nigerian law. Third, the maritime zones and jurisdictions claimed by Nigeria defined the territorial jurisdiction and consequential limits for the application of Nigerian law in marine areas. Given the growing offshore oil and gas industry and other ocean use interests, it was important not only to define the full jurisdictional extent, but also to ensure that sectoral laws governing the various marine uses and protection of the marine environment were properly spatially and functionally extended in the maritime zones as permitted in international law. This is because substantive law effectively serves to nourish the grant of maritime jurisdiction. Thus, key 
definitions in the sectoral and environmental legislation needed to be aligned with modernized definitions of maritime zones.

\section{The Comparative Approach}

\subsection{First Steps}

The first legislative step in the process of ocean law reform taken by the Ministry of Justice was the preparation of a Bill for An Act to determine the Maritime Zones of Nigeria and for Matters Connected Therewith, to replace the current Territorial Waters Act and the Exclusive Economic Zone Act. The legislative project would eventually evolve through a series of drafts and mature into the House/Senate Bill. ${ }^{40}$ The Bill proposed a new framework for the definition and exercise of national jurisdiction over ocean space and included a re-organization of existing legislation. The future statute would have particular features, including the implementation of an international convention, determination of the full extent of national territory established under the Constitution and provision for the application of national law to marine spaces. In particular, the last of these features is a major function of maritime zone legislation. The future statute would have the effect of providing the jurisdictions necessary to apply national law over a multitude of ocean uses in different maritime zones. Legislation that establishes, clarifies and confers marine jurisdiction is of value both for external (international) and internal (domestic) purposes. It serves to identify the limits of application of a broad range of national legislation concerning marine environment protection, fisheries, offshore development, shipping and navigation, maritime security and other ocean uses. At the same time, substantive law would nourish the grant and definition of jurisdiction. 


\subsection{Choice of Comparator Jurisdictions}

The review of the Draft Bill necessitated multi-dimensional analysis through a series of parallel tasks. The jurisdictional function to be performed by the future statute required crossreferencing to other relevant federal statutes in the interests of consistency within the legal system. This enabled an understanding of the "fit" of the Bill within the existing legislative scheme for the law of the sea and related matters in national law. The exercise identified statutes that could potentially be affected by the Bill so as to require consequential amendment.

Bearing in mind the principal purpose of the review to support modernization of maritime zones and related jurisdictions through the implementation of the LOS Convention, pertinent provisions of the latter instrument were used as benchmarks for specific sections of the Bill. This exercise ensured that Nigeria would exercise rights in compliance with treaty rights and obligations. The future statute would attract international attention with regard to the expectation of compliance, a right of all State Parties to the LOS Convention. ${ }^{41}$ There have been many instances in international State practice where the claims of a particular State triggered diplomatic protests from other States, ${ }^{42}$ a situation that Nigeria would want to avoid.

Prior to this legislative initiative, Nigeria's maritime zone and jurisdictional claims were contained in more than one statute, namely the Territorial Waters Act, Petroleum Act and the Exclusive Economic Zone Act as noted earlier. The Bill consolidates the modernized content of the Territorial Waters Act and Exclusive Economic Zone Act into a single integrating statute, repealing them in the process, and consequentially amends the Petroleum Act. In the preparation of the legislative project, Nigeria clearly stood to benefit from a close examination of the practices of other States that utilized the same or a similar approach by being better informed and considering good practices. This served to address one concern with the comparative law approach, 
namely, that to be useful, the comparison should have clear purpose(s). In this case, the purposes of comparison were to assist law reform, learn from the experience of other jurisdictions in the implementation of the LOS Convention and promote international uniformity. An important step at this level of analysis was the choice of jurisdictions for comparative purposes (Table 1). A number of criteria were identified to facilitate an appropriate choice, thus avoiding another potential pitfall of the comparative law approach, namely, arbitrary or unjustified comparisons. ${ }^{43}$ The main emphasis was on states that legislated maritime zones and jurisdictions in one statute.

Table 1: Comparator States

\begin{tabular}{|c|c|c|c|c|}
\hline $\begin{array}{l}\text { Comparator } \\
\text { level }\end{array}$ & Criteria & States & $\begin{array}{l}\text { Primary } \\
\text { geography }\end{array}$ & Instruments \\
\hline International & $\begin{array}{l}\text { Treaty to be } \\
\text { implemented }\end{array}$ & N/A & N/A & $\begin{array}{l}\text { UN Convention on the Law of the Sea } \\
1982\end{array}$ \\
\hline \multirow[t]{13}{*}{ National } & \multirow{3}{*}{$\begin{array}{l}\text { Federal } \\
\text { States }\end{array}$} & Canada & Continental & Oceans Act 1996 \\
\hline & & India & Continental & $\begin{array}{l}\text { The Territorial Waters, Continental } \\
\text { Shelf, Exclusive Economic Zone and } \\
\text { Other Maritime Zones Act } 1976\end{array}$ \\
\hline & & $\begin{array}{l}\text { South } \\
\text { Africa }\end{array}$ & Continental & Maritime Zones Act 1994 \\
\hline & \multirow{7}{*}{$\begin{array}{l}\text { States } \\
\text { having } \\
\text { similar } \\
\text { legislative } \\
\text { traditions }\end{array}$} & $\begin{array}{l}\text { The } \\
\text { Bahamas }\end{array}$ & $\begin{array}{l}\text { Archipelagic } \\
\text { State }\end{array}$ & $\begin{array}{l}\text { Archipelagic Waters and Maritime } \\
\text { Jurisdiction Act } 1993\end{array}$ \\
\hline & & Belize & Continental & Maritime Areas Act 1992 \\
\hline & & Canada & Continental & Oceans Act 1996 \\
\hline & & Ghana & Continental & $\begin{array}{l}\text { Maritime Zones (Delimitation) Law } \\
1986\end{array}$ \\
\hline & & $\begin{array}{l}\text { New } \\
\text { Zealand }\end{array}$ & Islands & $\begin{array}{l}\text { Territorial Sea and } \\
\text { Economic Zone Act } 1977\end{array}$ \\
\hline & & $\begin{array}{l}\text { South } \\
\text { Africa } \\
\end{array}$ & Continental & Maritime Zones Act 1994 \\
\hline & & Tanzania & Continental & $\begin{array}{lcc}\text { Territorial Sea and } & \text { Exclusive } \\
\text { Economic Zone Act } 1989 & \end{array}$ \\
\hline & \multirow[t]{3}{*}{$\begin{array}{l}\text { Regional } \\
\text { States }\end{array}$} & Ghana & Continental & $\begin{array}{l}\text { Maritime Zones (Delimitation) Law } \\
1986\end{array}$ \\
\hline & & Kenya & Continental & The Maritime Zones Act 1989 \\
\hline & & Namibia & Continental & $\begin{array}{l}\text { Territorial Sea and Exclusive } \\
\text { Economic Zone of Namibia Act 1990, } \\
\text { as amended in } 1991\end{array}$ \\
\hline
\end{tabular}




\begin{tabular}{|l|l|l|l|l|}
\hline & & $\begin{array}{l}\text { South } \\
\text { Africa }\end{array}$ & Continental & Maritime Zones Act 1994 \\
\cline { 2 - 5 } & Tanzania & Continental & $\begin{array}{l}\text { Territorial Sea and Exclusive } \\
\text { Economic Zone Act 1989 }\end{array}$ \\
\cline { 2 - 5 } & $\begin{array}{l}\text { States with } \\
\text { recent (post } \\
1994) \\
\text { legislation }\end{array}$ & $\begin{array}{l}\text { Canada } \\
\text { Africa }\end{array}$ & Continental & Oceans Act 1996 \\
\cline { 2 - 5 } & $\begin{array}{l}\text { Western } \\
\text { Samoa }\end{array}$ & Island & Maritime Zones Act 1999 \\
\cline { 2 - 5 } $\begin{array}{l}\text { Other States } \\
\text { with } \\
\text { maritime } \\
\text { zone statutes } \\
\text { of interest }\end{array}$ & Cyprus & Island & $\begin{array}{l}\text { Contiguous Zone Law of 2004; } \\
\text { Exclusive Economic Zone Law of } \\
\text { 2004 }\end{array}$ \\
\cline { 2 - 5 } & Jamaica & Archipelagic \\
State & $\begin{array}{l}\text { Exclusive Economic Zone Act 1991; } \\
\text { Maritime Areas Act 1996 }\end{array}$ \\
\cline { 2 - 5 } & Pakistan & Continental & Exclusive Economic Zone Act 1984 \\
\cline { 2 - 5 } & $\begin{array}{l}\text { Papua } \\
\text { New } \\
\text { Guinea }\end{array}$ & Islands & $\begin{array}{l}\text { Territorial Waters and Maritime Zones } \\
\text { Act 1976 }\end{array}$ \\
\cline { 2 - 5 } & Vanuatu & $\begin{array}{l}\text { Archipelagic } \\
\text { State }\end{array}$ & The Maritime Zones Act 1981 Seas Act 1977 \\
\hline
\end{tabular}

The criteria used for choice of jurisdictions for comparison, in addition to integrating statutes, included federal systems, legal tradition, regional state practice and most recent state practice. The resulting comparator group was a sample of states chosen because they met one or more criteria. As a federal state, Nigeria's new statute defining and conferring jurisdiction has to contend with complex issues of intergovernmental distribution of powers and related matters. It was useful to consider Canada, ${ }^{44}$ India $^{45}$ and South Africa ${ }^{46}$ as potential comparator jurisdictions. The driver was not similarity of federal systems but rather the challenges posed by subnational distribution of powers that has the potential to contribute to applicable law and, thereby, affect regulation of marine activities. The new statute would benefit from comparison with analogous legislation from other common law jurisdictions and that shared similar legislative traditions. The jurisdictions that were useful in this regard were The Bahamas, ${ }^{47}$ Belize,${ }^{48}$ Canada, Ghana, ${ }^{49}$ New Zealand, ${ }^{50}$ South Africa and Tanzania. From an African regional perspective and the geographical 
context of Nigeria, it was useful to consider practices of particular African States because of adjacency to Nigeria, or their geographical location and characteristics in the region. These included Ghana, Kenya, ${ }^{51}$ Namibia, ${ }^{52}$ South Africa and Tanzania. ${ }^{53}$ Finally, the comparative law exercise had to ensure that reference was made to the most recent legislative practices to ensure consideration of state of the art legislation. These jurisdictions would have adopted maritime zone legislation relatively recently and after the LOS Convention came into force in 1994. These jurisdictions included Canada, South Africa and Western Samoa. ${ }^{54}$ There were other jurisdictions that legislated maritime zones and jurisdictions in more than one instrument whose approach to one or more statute and/or particular provisions was considered, including Cyprus, ${ }^{55} \mathrm{Jamaica}^{56}$ Malaysia, ${ }^{57}$ Pakistan $^{58}$ Papua New Guinea ${ }^{59}$ and Vanuatu. ${ }^{60}$ This exercise helped to identify a number of jurisdictions (for example Canada and South Africa) that satisfied more than one criterion and, consequently, justified frequent comparison. Geography was also a consideration, as Nigeria's coastal frontage concerns are likely to be closer to those of other continental States. However, it was important not to exclude potentially useful and applicable lessons for particular maritime zones and jurisdictions irrespective of geography; this is why the legislation of some island States were also consulted, although to a lesser extent.

\subsection{Analytical Criteria}

Having identified the comparator jurisdictions, the next step was to develop analytical criteria to guide multi-layered comparative analysis of the Bill. A key objective in the ocean law reform process was maximization of benefits conferred by and in compliance with the LOS Convention. Thus, the extent to which the Bill maximised the maritime zones and related jurisdictions as permitted by the Convention was a controlling criterion. It was also essential to 
ascertain consistency with the Convention, in addition to benefit maximization, because the new instrument would also be an expression of Nigeria's implementation of rights and responsibilities under international law.

The maritime zone and jurisdictional entitlements in the LOS Convention are defined in spatial, scientific and functional modes. In particular, given the importance of Nigeria's initiative to claim the extended continental shelf, it was important to consider scientific and technical criteria in support of the definition of the outer edge of the continental shelf in accordance with article 76 of the Convention. Also important was appropriate provision for the establishment of baselines from which the breadth of the various maritime zones and jurisdictions would be measured. Closely related to the use of scientific and technical criteria, it was important to ensure clarity of the extent and type of jurisdictions claimed.

Textual precision, clarity and consistency were another package of criteria to assess quality of drafting. Precision (extent to which drafting is faithful to the treaty text) was important to ensure conformity with the provisions of the LOS Convention. Textual clarity would avoid unnecessary difficulties in the exercise of legislative and enforcement jurisdiction. Consistency was important to ensure readability with other legislative instruments and the rest of the legal system. In particular, consistent and correct use of key law of the sea concepts in the Bill and related statutes had to be ascertained.

Provisions to support the extension of the application of existing federal and state public and private law, as appropriate, to marine areas, were essential. Nigeria has a vibrant offshore oil and gas industry, but at the time of the study, it was not clear the extent to which the Nigerian legal system applied to activities on board offshore installations and structures. While contractual obligations and regulatory matters, such as those governing program of work, maritime safety, 
occupational health and safety and marine environment protection were not necessarily at issue, a moot point was the extent to which pertinent aspects of private and public law apply on an extraterritorial basis (i.e., outside the territorial sea) where Nigeria did not enjoy full sovereignty, i.e., the totality of jurisdictions that it would exercise on land territory. It was conceivable that contracts and wills could be concluded or torts committed on an installation, matters governed by federal and not sub-national state law. Indeed, it was unclear whether provision had ever been made to extend the application of the common law beyond the limitations imposed by $R . v . K e y n,{ }^{61}$ thus constraining the exercise of jurisdiction by state courts as distinct from the Federal High Court. Consequently, in the Nigerian federal system, there are often strong jurisdictional contestations not only between federal and state, but among all levels of government over their spheres of authority, a situation that transforms the courts into theatres of constitutional challenge, including in relation to the uses of the marine areas. ${ }^{62}$ Such contestations would only be compounded if more matters are left in the grey zone in this issue area.

As indicated earlier, in setting out the jurisdictional framework the Bill effectively enables the application of laws that nourish the functional jurisdictions concerned (e.g., over fisheries, offshore oil and gas and marine environment protection). Hence the analysis required crossreferencing to provisions in other legislation because the Bill would consequentially amend other statutes to the extent of the inconsistency. This aspect of the analysis entailed further consideration of possible transitional requirements, repeals and consequential amendments. 


\section{Comparative Analysis}

\subsection{Policy Rationale}

A statute that declares national maritime zones and jurisdictions is an instrument which, while not necessarily being a constitutional law instrument, performs vital constitutive functions because it helps to define the extent of national territory and authority exercised at sea. Accordingly, such an instrument would be expected to have policy rationale, whether explicit or implicit. For example, the Oceans Act of Canada sets out the policy rationale in its preamble, embracing the totality of ocean use and management objectives of the LOS Convention, including sustainable resources utilization and conservation and marine environment protection as a collaborative undertaking among government, stakeholders and other interested parties. ${ }^{63}$ Ghana similarly states the purpose of its Maritime Zones Delimitation Act which is primarily related to implementation of the LOS Convention. ${ }^{64}$

Nigeria does not have an explicit ocean policy (i.e., declared in the form of a policy instrument), nor does the Bill include a preamble to explicitly state its policy rationale. However, it is clear that the Bill is triggered by policy considerations, such as the need to maximize new entitlements, and for Nigeria to position itself to fulfil responsibilities under the LOS Convention, establish a modern framework for legal ordering in maritime zones and facilitate the application of Nigerian law to maritime activities by executive and judicial bodies. The Bill also aims to identify ministerial roles and address specific issues of particular concern, such as to streamline offshore exploration of mineral resources, including petroleum and gas, and to supplement the new constitutional derivative regime established, as noted earlier, under article 162(2) of the 1999 Constitution. 


\subsection{Structure of the Legislative Scheme}

State maritime zone legislative practice evidences differences in the approach to implementation of the LOS Convention (i.e., structure), but some major trends are discernible. A first approach is for states which assert, in a basic manner, the maritime zones and jurisdictions allowed under the Convention. The most basic structure is a serial claim to all the zones through legislative provision which is consistent with the conventional law text. An example of this approach is Ghana, ${ }^{65}$ with slight variations in the cases of Namibia and South Africa. ${ }^{66}$ The appealing feature of this minimalist approach is simplicity and the wide scope of zonal rights and jurisdictions that it permitted. Frequently in such statutes, there is little, if any attempt to domesticate the zonal and jurisdictional claims to specific interests or issues. The maritime zones statute tends to list other statutes affected by its reach, indicating what statutes are subject to repeal or amendment.

A slight variation on this approach explicitly addresses issues of concern at the same time as it asserts by routine reproduction, relevant LOS Convention rights and jurisdictions. In this case, the noticeable feature is the emphasis, through detailed provisions, on activities of interest or consequence for the integrity of a state's rights and jurisdiction in each claimed zone. For instance, The Bahamas' legislation is detailed in its powers to control and regulate navigation in its archipelagic and other waters. ${ }^{67}$ Jamaica makes provision regarding the passage of warships and vessels that transport nuclear or other dangerous or noxious substances. ${ }^{68}$ Jamaica also has separate legislation in which it claims and regulates its EEZ rights and jurisdiction generally ${ }^{69} \mathrm{In}$ addition, it provides the Minister with regulatory authority over all economic activities that may be undertaken in the EEZ. ${ }^{70}$ It also provides for offences and the powers to be exercised by designated authorities for enforcing and applying appropriate sanctions for breaches of applicable laws. ${ }^{71}$ 
A second approach involves thematic arrangement. This has been followed by, among others, Belize, Kenya, New Zealand and Tanzania. ${ }^{72}$ Although the statutes of these States vary in the amount of detail and attention to particular issues, their provisions tend to be aggregated in groups or clusters according to commonality of subject-matter. ${ }^{73}$ The application of existing substantive and procedural law is extended to the maritime zones and jurisdictions claimed, either generally or specifically. In the case of a general extension, the existing substantive law in the State is extended to the maritime zones to the extent of the statute's purposes and objectives. Kenya and Tanzania are good examples of this practice. ${ }^{74}$ Essentially, their laws make basic assertions to rights and jurisdictions consistent with the LOS Convention. However, Kenya's statute provides details regarding the regulatory authority of the Minister, ${ }^{75}$ while Tanzania's is more detailed on the powers of the agencies entrusted with exercising the jurisdictions specified in the provisions of the legislation. ${ }^{76}$ In comparison, the legislation of Ghana and Namibia, both examples of the first approach, lack such features. Belize exemplifies the second approach by structuring the Act in various parts, including a specific part on charts and geographical co-ordinates of maritime zones, a separate part on the jurisdiction of the courts to entertain matters arising under the statute and the powers and procedures of enforcement agencies. ${ }^{77}$ New Zealand's legislation, which predates the LOS Convention, has a similar structure while containing more detailed provisions on fisheries rights and jurisdiction within the EEZ. ${ }^{78}$

A third approach is exemplified by Canada's Oceans Act 1996. This statute exhibits the structured arrangement of the second approach but premised by overarching national ocean policy founded on sustainable, integrated and precautionary use, and providing a framework for management, conservation and protection of coastal and ocean systems and their resources. ${ }^{79}$ For this reason, provisions relating to basic rights and jurisdictional claims within the various maritime 
zones are not the only provisions in the Act. They set out a legal framework for the administration of the maritime zones, followed by policy and institutional frameworks to enable and facilitate integrated management of Canada's maritime zones. ${ }^{80}$ The amplitude of conventional law rights and jurisdictions in each maritime zone is claimed. In defining the basis for legislative and enforcement jurisdiction, the Oceans Act provides for the extension of application of federal and provincial law, as well as the jurisdiction of the courts. ${ }^{81}$ From an institutional perspective, mandatory and discretionary duties and powers are conferred on the Minister, working in collaboration with other ministers, to lead the development of a national oceans strategy and integrated management planning, and to make regulations for the achievement of the aims of the Act. $^{82}$

The approach adopted by Nigeria in the House/Senate Bill is a blended one, drawing on the first and second types described above. While not breaking down the scheme into thematic sub-titles, by and large it follows the progression of articles on baseline delineation and maritime zones in the LOS Convention, while simultaneously clarifying authority and jurisdiction (legislative and enforcement) in each maritime zone. ${ }^{83}$

\subsection{Constitutional Issues}

As indicated earlier, maritime zone legislation has both territorial and extra-territorial dimensions. One issue that arises in this regard is definition of national territory, normally a constitutional provision. Definition of national territory clarifies the geographical scope or limits for jurisdictional purposes. The Constitution of the Federal Republic of Nigeria 1999, does not have a provision that defines in geographical terms the territory of the federation, terrestrial and maritime, including internal and territorial waters. ${ }^{84}$ Similarly, Ghana does not have a 
constitutional definition or provision for delimitation of its geographical space, but has a constitutional provision that directly vests Parliament with such legislative powers over its entire geographical space. ${ }^{85}$ The Philippines is an example of a State that defines and delimits its geographical space in the constitution. ${ }^{86}$ It should be noted that definition of national territory is a very sensitive matter for Nigeria, especially at a time when a joint boundary commission with Cameroon is in the process of demarcating terrestrial (including inland waters) and delimiting maritime boundary with that state.

A related matter is the vesting of maritime zones in the Federal Government of Nigeria. The absence of a constitutional definition of national territory does not mean that the Constitution is altogether silent on the subject. Article 44(3) provides that:

... [T] he entire property in and control of all minerals, mineral oils and natural gas in, under or upon any land in Nigeria or in, under or upon the territorial waters and the Exclusive Economic Zone of Nigeria shall vest in the Government of the Federation and shall be managed in such manner as may be prescribed by the National Assembly. ${ }^{87}$

This article provides, first, for vesting resource rights in the Federal Government and second, for their management as may be legislated by the National Assembly. Until the Bill addressed the matter, there was an anomaly in this vesting provision insofar as the extended continental shelf is concerned. While the EEZ clearly covers areas within 200 nautical miles, the continental shelf beyond the EEZ is not included in article 44(3). There is other legislation that refers to the continental shelf, in particular the Petroleum Act $1969,{ }^{88}$ but obviously this also does not address vesting of rights at the highest level of law-making in regard to the extended continental shelf. There is a similar issue in the Minerals and Mining Act. ${ }^{89}$

The House/Senate Bill attempts to address this problem by vesting the continental shelf, including its extension to the outer limits permitted under international law and practice, in the federal government. ${ }^{90}$ As indicated earlier, such legislation has a constitutive character, but the 
House/Senate Bill is not constitutional, with the consequence that its sections 13(1) and 14(1) regarding vesting of continental shelf rights ${ }^{91}$ may have a doubtful constitutional basis, if any. The long-term solution of this anomaly will be a constitutional amendment that would include the continental shelf in article 44(3) of the 1999 Constitution.

\subsection{Transition of Legal Regimes}

A major change introduced by the Bill is the incorporation of the LOS Convention regime for the determination of the seaward limits of the continental shelf. In particular, article 76 of the Convention enables Nigeria to claim the entire continental margin and not just the continental shelf as provided under article 1 of the Geneva Convention on the Continental Shelf 1958. Nigeria acceded to the Geneva Convention on 28 April 1971 and ratified the LOS Convention on 14 August 1986. On coming into force on 16 November 1994, the LOS Convention prevailed over the Geneva Convention in relation to those States that are parties to both conventions. ${ }^{92}$ The full transition from one conventional regime to another would occur when the House/Senate Bill becomes law. The Petroleum Act defines the continental shelf as provided in the Geneva Convention. ${ }^{93}$ The Bill has consequentially amended this provision. ${ }^{94}$

\subsection{Maximization of Maritime Zone Benefits}

\subsubsection{Baseline delineation}

Under the old regime, Nigeria was not positioned to fully maximize maritime zone benefits it is entitled to in the LOS Convention. The determination of the seaward limits of maritime zones is dependent on the rules for baselines, and the omission of particular features may have a significant influence on the seaward extent of the maritime zone claimed. Early versions of the 
Bill paid insufficient attention to geographical features. For example, other than referring to the "coast," there was no further reference to the utilization of low-tide elevations, whether for purposes of delineating the normal baseline, or for the identification of base-points for use of the straight baseline method, including permanent harbor works as permitted by the LOS Convention ${ }^{95}$ and as practised by other jurisdictions such as Belize and South Africa. ${ }^{96}$

Much of the Nigerian coastline is a delta or a system of deltas, highly indented and cut into, qualifying it for the application of the straight baseline method. ${ }^{97}$ The coastline also has several bays that would satisfy the 'semi-circle/closing line' rule for bays. ${ }^{98}$ There was lack of clarity regarding the application of the straight baseline system, which is to be distinguished from closing lines for bays. ${ }^{99}$ There was useful practice indicating how closing lines could be legislated. ${ }^{100}$ Further, it was unclear which Minister or other appropriate authority is responsible for baseline delineation, the designation of officially recognized charts or their preparation and the giving of due publicity to them. ${ }^{101}$

The House/Senate Bill rectified these weaknesses by closely aligning the baseline delineation provisions with the LOS Convention stipulations. ${ }^{102}$ A ministerial power to delineate baselines was included, as well as provision for the designation of officially recognized charts, thus addressing the issue of legal authority for designating baselines. ${ }^{103}$ This change will consequentially affect baseline definition in the National Inland Waterways Act. ${ }^{104}$

The consequence of straight baseline and closing line delineation is that waters on the landward side will have the status of internal waters, i.e., to be treated similarly to land territory. Nigerian legislation frequently refers to inland waters, ${ }^{105}$ which generally are considered as waters separate from internal waters. In one statute the concept of internal waters is used and defined and distinguished from inland waterways. ${ }^{106}$ However, the key Interpretation Act, while defining 
inland waters does not define internal waters. ${ }^{107}$ This complex practice necessitated streamlining the use of the concept of internal waters, which was addressed by the Bill ${ }^{108}$ while drawing on the practice of other States. ${ }^{109}$

\subsubsection{Territorial sea}

In general, and as noted earlier, for Nigeria to fully benefit from its maritime zones, the statute would need to ensure that the application of Nigerian laws and regulations is extended for the maritime zone concerned as permitted by the LOS Convention. The territorial sea (in addition to internal waters) is a zone within which Nigeria enjoys sovereignty and, therefore, the totality of laws and jurisdictions exercisable on land territory could be exercised in internal and territorial waters, as long as this is properly provided for in law. The Bill's provision concerning the assertion of sovereignty in the territorial sea is consistent with analogous provisions in the practice of other States. ${ }^{110}$

The exercise of sovereignty in the territorial sea is not without bounds; in fact, it is subject to the regime of innocent passage ${ }^{111}$ as a right of international navigation. The coastal State is empowered to regulate innocent passage,,${ }^{12}$ and there is a duty for foreign ships to respect the laws and regulations of the coastal State enacted for this purpose within the bounds of the Convention. ${ }^{113}$ A potential difficulty is the exercise of enforcement jurisdiction. In this respect, the Bill sets out a framework which, while clearly providing full enforcement jurisdiction for Nigerian authorities and courts, shows restraint in terms of the requirement for a certificate by the Attorney-General to authorize trial in the case of persons who are not Nigerian nationals. ${ }^{114}$ This enables the AttorneyGeneral to ascertain that jurisdiction may, in fact, be exercised over foreign nationals, especially with regard to provisions in the Convention that restrict the exercise of criminal law jurisdiction. ${ }^{15}$ 
Two other provisions that merit brief mention, especially considering Nigeria's active maritime boundary negotiations with neighbours, concern the delimitation of territorial sea boundaries for which the Convention provides a specific rule, ${ }^{116}$ and alteration of the seaward limits of the territorial sea. Consistently with the LOS Convention and state practice, the Bill prescribes a median equidistant boundary in the absence of agreement. ${ }^{117}$ The Bill also empowers the Minister or Appropriate Authority to amend by regulation the outer limits of the territorial sea as necessary. ${ }^{118}$

\subsubsection{Contiguous zone}

Like many other African States, until the House/Senate Bill, Nigeria had no legislative provision for the contiguous zone. ${ }^{119}$ This maritime zone has a maximum breadth of 12 nautical miles commencing from the outer seaward limit of the territorial sea. It extends preventive and enforcement jurisdiction for the coastal state's customs, fiscal, immigration and sanitary laws and regulations. ${ }^{120}$ Only offences committed in the territory or territorial sea (not contiguous zone) may be punished. The contiguous zone is an enforcement area for offences committed on sovereign territory (i.e., territory or territorial sea) and for the taking of measures to prevent the infringement of such laws on that territory.

The literature suggests that contiguous zone jurisdiction has the potential to contribute to combating problems experienced by African States, such as the illegal traffic in endangered species (through customs regulation), illegal transboundary movement of hazardous wastes (through customs and health regulation) and various forms of human trafficking, especially of women, children and the most vulnerable (immigration regulation). ${ }^{121}$ The House/Senate Bill claims this zone with all its benefits. ${ }^{122}$ 
Nigeria had also not claimed jurisdiction to protect submerged archaeological and historical objects and their trafficking in the contiguous zone. ${ }^{123}$ Differently from the customs, immigration, fiscal and sanitary jurisdictions, this power permits action to prevent and punish the removal and trafficking of such objects in the contiguous zone, as distinct from the territory or territorial waters of Nigeria. The experience of South Africa and Cyprus in legislating this jurisdiction was considered. ${ }^{124}$ The House/Senate Bill has addressed this omission with an appropriate provision claiming this jurisdiction. ${ }^{125}$ In relation to all contiguous zone jurisdictions, the power to regulate is conferred on the Minister, while the exercise of the powers of arrest and seizure requires the consent of the Attorney-General, and the Federal High Court is designated as the competent court. ${ }^{126}$

\subsubsection{Exclusive economic zone}

Nigeria first legislated the 200-nautical mile EEZ in 1978 in the Exclusive Economic Zone Act at a time when the concept had become part of customary international law, but before the negotiating text of the LOS Convention was finalized and adopted. The Act was essentially declaratory in function and did not fully spell out the jurisdictions that could be exercised by Nigeria. ${ }^{127}$ While jurisdiction over artificial islands, installations and structures was claimed, ${ }^{128}$ jurisdictions for marine environment protection and marine scientific research permissible in the LOS Convention were not specifically claimed. ${ }^{129}$ The legislation of comparator States on these provisions showed that jurisdiction for marine environment protection and marine scientific research tended to be specifically claimed and in the better practices, the legislative text tends to be aligned with the text of the Convention to ensure conformity. ${ }^{130}$ 
The House/Senate Bill improves the jurisdictional provisions on the EEZ and repeals the old Act. In text closely aligned to article 56 of the Convention, the sovereign rights and jurisdictions are spelled out clearly and fully consistently with the conventional text. ${ }^{131}$ An interesting addition is provision for the possible modification of the exercise of sovereign rights which may occur by treaty. ${ }^{132}$ This is a practical provision and considers the joint development zones that Nigeria has concluded with Equatorial Guinea and São Tomé e Príncipe, as noted earlier. Provisions on artificial islands, installations and structures are expanded and significantly improved from the 1978 Act. ${ }^{133}$ More resource and ocean-use specific provisions regarding the EEZ are generally not necessary in the Bill because the substantive law that nourishes the sovereign rights and jurisdictions in the EEZ will normally be set out in dedicated statutes.

\subsubsection{Continental shelf}

The continental shelf regime is the area of most pronounced legislative change in the House/Senate Bill. Prior to the Bill, the legal definition of the continental shelf in Nigeria's Petroleum Act was based on the Geneva Convention on the Continental Shelf 1958, rather than on the LOS Convention, significantly limiting the legislative basis for a full article 76 definition. ${ }^{134}$ Also, it was unclear where the legal authority to define the extended continental shelf resided without further legislative treatment. Primary legislation cannot be expected to define the precise outer limit, but rather to set out general provisions and empower appropriate ministerial authority to define the outer limits through subsidiary legislation in due course, after the Commission on the Limits of the Continental Shelf considers Nigeria's submission and provides recommendations upon which Nigeria proceeds to define the outer limit. 
The definitional provision adopted in the Bill benefitted from consideration of diverse state practice providing options. South African and Namibian legislation provided for referential incorporation of the definition of the continental shelf in the LOS Convention. ${ }^{135}$ Economical as it appears, this provision still relies on some form of executive act defining the outer limit, and in fact South Africa's Act provides for the designation of the outer limit in the form of limits set out in a schedule to the Act. ${ }^{136}$ This is important because a Nigerian court or enforcing authority cannot simply rely on a definition by referential incorporation. Differently, the Canadian and Jamaican approaches embraced a larger provision on definition and closely aligned to the text of article 76 of the Convention. ${ }^{137}$ Jamaica had a separate concern regarding the use of its archipelagic baselines, which is not a concern for Nigeria. ${ }^{138}$ Canada then proceeded to empower the Governor in Council upon the recommendation of the Minister of Foreign Affairs to make regulations respecting the actual outer limit of the continental shelf. ${ }^{139}$ In the end, this practice guided the Nigerian Bill only up to a point. Nigeria opted for a blended approach. It embraced the core aspects of the article 76 definition of the continental shelf in the Convention. Curiously, it legislated the constraint line of 350 nautical miles ${ }^{140}$ rather than the broader options permitted by the Convention, which states that the outer limit 'shall not exceed 350 nautical miles from the baselines from which the breadth of the territorial sea is measured or [emphasis added] shall not exceed 100 nautical miles from the 2,500 metre isobath, which is a line connecting the depth of 2,500 metres. ${ }^{141}$ One explanation might be that the scientific and technical work commissioned by Nigeria, which was completed by the time the Bill was introduced to the House, could only justify the 350 nautical mile constraint line.

In addition to the definition of outer limits, the LOS Convention also requires the coastal state to deposit with the UN and International Seabed Authority charts of appropriate scale and 
information, including geographical coordinates, describing the outer limits of its continental shelf. ${ }^{142}$ In this regard, Belize mandated the Minister with a set of tasks for this purpose, including: to prepare such charts and coordinates for baselines and all maritime areas (not just the continental shelf); to certify charts and copies to enable them to be used as evidence; and to give charts and coordinates due publicity and to submit them to the UN. ${ }^{143}$ The Canada Oceans Act also empowers the Minister to issue similar certification for evidentiary purposes. ${ }^{144}$ The Nigeria Bill empowers the Minister or Appropriate Authority, who may, by regulation, require preparation of charts describing the permanent outer limits of the continental shelf and to submit these and other relevant information to the UN. ${ }^{145}$

Sedentary species are the only living resources on the continental shelf over which the coastal State enjoys sovereign rights to explore and exploit. This is also not clearly legislated in Nigeria. ${ }^{146}$ This lacuna was rectified in the House/Senate Bill. ${ }^{147}$ While the Bill provides for consequential amendments based on inconsistency with provisions of the Act, it is unclear whether this provision applies to definitions which omit reference to sedentary species altogether. The definition of 'fish' in the Sea Fisheries Act is limited to marine fauna ${ }^{148}$ and, therefore, does not include non-faunal organisms that are known to exist or that may be discovered in the future.

The LOS Convention provides the coastal State with exclusive jurisdiction over artificial islands, offshore installations and structures. ${ }^{149}$ Prior to the Bill, it was not clear whether the rules regarding artificial islands, installations and structures applied to the continental shelf outside 200 nautical miles in addition to the EEZ. This ambiguity has been addressed in the House/Senate Bill. ${ }^{150}$

The Bill includes provision for transboundary single geological structures. ${ }^{151}$ Common in maritime boundary (especially continental shelf) agreements, this clause provides for cooperation 
among neighbouring States in the event a transboundary non-living resource is discovered and to enable its proper development and utilization. As a matter of good oilfield practice, the boundaries of a reservoir need to be delineated in order to enable an assessment as to how best to exploit the deposit to maximise production. There have been several situations in the North Sea and Southeast Asia where transboundary reservoirs have been discovered and exploited cooperatively, either through unitization or joint development. In Nigeria's case, a transboundary resource could be shared either with a neighbouring state or with the international seabed area, which is administered by the International Seabed Authority. It is unusual to see it legislated in a statute. The Nigerian Bill effectively establishes a precedent.

From one iteration of the Bill to another, there was discussion on whether the Bill should include a provision regarding submarine cables and pipelines, a substantive marine use rather than a jurisdictional issue, the laying of which is a protected international community right in the Convention. As it was felt there was no other appropriate statute within which to locate a provision on cables and pipelines, the Bill includes a clause on the subject. ${ }^{152}$

\subsection{Court Jurisdiction}

The creation of a cause of action does not automatically confer jurisdiction on courts. There is need to ensure that there is always a competent court that has jurisdiction for causes of action that arise in a maritime zone, whether ratione loci (by location of the cause) or ratione materiae (by subject-matter of the cause). In many cases, admiralty law may govern causes traditionally entertained by the Admiralty Court (e.g., torts in a maritime setting). In Nigeria, the competent court with principal jurisdiction over many possible marine causes is the Federal High Court (which also enjoys Admiralty jurisdiction). ${ }^{153}$ This is important because the Federal High Court is 
a statutory creation and, therefore, a court of limited jurisdiction. The limits of its jurisdiction are defined by the empowering statute. However, the Draft Bill was likely not exhaustive of all possible causes of action arising from activities in Nigeria's maritime zones, e.g., common law causes in contracts and torts. Civil suits may arise on subject-matter or circumstances that may implicate other laws of Nigeria and its component states, in which case a court other than the Federal High Court could potentially be a more appropriate forum in terms of competence ratione materiae. While the Federal High Court Act empowers the Court to transfer proceedings to a more appropriate court, a situation that could conceivably arise where the appropriate or convenient court, although having competence over subject-matter, may not have the jurisdiction necessary over a cause of action arising in a maritime zone. The House/Senate Bill has addressed this issue by providing that all enactments conferring criminal and civil (including torts) jurisdiction in all parts of Nigeria must apply to acts and omissions that take place in all Nigeria's maritime zones. As well, the appropriate forum must assume jurisdiction to apply the relevant legislation, including rules of court. ${ }^{154}$ It is hardly possible, however, to preempt all jurisdictional issues in a piece of legislation like the House/Senate Bill. A lot more would become clearer over time through litigation and implementation experience.

\subsection{Extension of Application of Nigerian Laws to Maritime Zones}

Although a good practice, it is not common for national maritime zone legislation to specifically provide for the extension of application of national law to nourish the acquired rights and jurisdictions. Canada made specific provision for such application and even empowered the Minister to extend the application of provincial laws to the maritime zones. ${ }^{155}$ Like Canada, Nigeria's vibrant offshore industry necessitates a substantial workforce living on offshore 
installations for significant periods of time. It is conceivable for private law transactions to occur in the daily life of the offshore work community and in which case the common law is important for orderly transactions. South Africa anticipated this need and specifically legislated the extension of the common law in its maritime zones. ${ }^{156}$

The experience of Canada and South Africa was useful in guiding the House/Senate Bill in making provision for the application of Nigerian law in the maritime zones. The exercise of jurisdiction for public law purposes was addressed in several provisions with regard to each maritime zone. ${ }^{157}$ In particular, provision was made for the application of criminal and civil laws in the maritime zones, and definition of enactment to include 'any Act or law relating to criminal or civil law (including torts) and any subsidiary instrument made hereunder, including rules of court and in matters other than criminal matters, rules of law applicable to or adopted in any part of Nigeria. ${ }^{, 58}$ The latter phrase is sufficiently wide to include federal and state legislation on civil subjects as well as the common law. The Bill also anticipates the need to extend judicial competence (i.e., Federal High Court jurisdiction) to entertain cases whose causes of action occur in the maritime zones. ${ }^{159}$

\subsection{Institutional Responsibilities and Administrative Powers}

It is common practice for maritime zone legislation to identify lead institutional responsibilities for the administration of the Act. It is conceivable that responsibilities are allocated to more than one Minister, as in the case of Canada's Oceans Act where the Minister of Fisheries and Oceans is tasked with the lead role for integrated ocean management, while other responsibilities are allocated to the federal Ministers for Foreign Affairs and Justice. ${ }^{160}$ With the exception of provisions that are exclusively a responsibility of the Minister of Justice, ${ }^{161}$ the 
House/Senate Bill takes a neutral approach to the allocation of institutional responsibilities by referring to the 'Minister or Appropriate Authority' rather than designate a specific ministry. ${ }^{162}$ The overall effect is that, unlike Canada, Nigeria's Bill does not allocate a principal lead role, but rather tasks a number of ministries which may be allocated functions under the future statute or nominated or invited pursuant to presidential discretion as the case may be from time to time. There are numerous areas in the Bill where existing mandates of various ministers, for example, concerning living and non-living resources and protection of the marine environment, require effective cooperation and coordination to achieve desired outcomes.

Finally, drawing primarily on the Canadian experience in the Oceans Act, ${ }^{163}$ the Bill provides the Minister or Appropriate Authority with the 'Power to make regulations' for the purposes of administration of the Act. ${ }^{164}$ The subject-matter for regulation includes activities in maritime zones, resource regulation, artificial islands, installations, structures and devices, marine environment protection, and marine scientific research. The areas suggest that by their mandates, various main line ministries will be able to exercise regulatory authority in any maritime zone.

\subsection{Final Provisions}

\subsubsection{Supremacy, repeals and consequential amendments}

Any major piece of legislation, such as the subject of the House/Senate Bill, needs to be carefully and seamlessly woven into the legal system. This is not simply a matter of coherence and consistency among marine legislations generally. It is also necessary to engage other structures of substantive law and procedure (e.g., civil and criminal law and procedure) of the legal system, as these are critical for the enforcement of the future Act. On this score, the provisions that the House/Senate Bill makes regarding its relations with preceding legislations relevant to the marine 
sector in terms of their continuity or otherwise, are important for understanding how it fits into the existing legal structure and its operations.

The salience of the foregoing point is reiterated by the fact that national maritime zones legislation is enacted generally to enable the application of relevant domestic laws in conformity with the provisions of the LOS Convention which is a multilateral treaty. Consequently, the Convention-implementing legislation tends to establish the priority of its rules over other national laws that are relevant to the use and regulation of national maritime zones. It may achieve this outcome by expressly or interpretively making the provisions of the maritime zones legislation the supreme applicable rules in the issue-area. It may also achieve it by repealing and/or consequentially amending the laws affected by its enactment.

The establishment of blanket supremacy of the maritime zones legislation over other relevant legislations is not common. Among our comparator jurisdictions, only Belize adopted this approach to make the provisions of its maritime zones legislation supreme over every other law, rule or regulation. ${ }^{165}$ Kenya and South Africa did similarly, but in a more instrumental manner. Kenya's legislation provides that the meaning attached to the territorial sea and Exclusive Economic Zone in all other laws must conform to their legal and functional status under the maritime zones legislation. In the South African maritime zones legislation, references in other laws to any zone it legislates must be read and understood in the light of its provisions. In particular, it specifies that fisheries conservation, management or exploitation, as well as contiguous zone functions mandated under any other law must be interpreted and observed in light of its provisions. ${ }^{166}$

Priority or supremacy has also been provided and further strengthened by means of repeals and consequential amendments set out in the maritime zones legislation in respect to the laws that 
are affected by its adoption. In utilizing this approach, our comparator jurisdictions have demonstrated differing degrees of specificity and detail. Some identified which preceding laws were wholly repealed by their maritime zones legislation without indicating whether any other domestic laws in force may be read in light of its provisions. ${ }^{167}$ Others specified repeals and also identified other laws that were consequentially amended, including the extent of amendments to sections of those laws as engendered by the provisions of the maritime zones legislation. ${ }^{168}$ Canada's Oceans Act offers the most elaborate example of this. ${ }^{169}$ Jamaica was similarly inclined when it adopted its Exclusive Economic Zone Act. Jamaica accompanied its repeals and consequential amendments with explanations of their rationales and objectives which were identified to the nature of the legal regime of the exclusive economic zone provided for in the LOS Convention. ${ }^{170}$ New Zealand put a slight variation on these approaches: it specified repeals and amendments, but expressly provided that the overarching ocean legislation was not supreme but complementary to existing applicable laws. ${ }^{171}$

During various reiterations of the House/Senate Bill, and by virtue of its emerging provisions necessitated by the relevant rules of the LOS Convention, existing Nigerian legislations utilized for cross-referencing were identified as subject to consequential amendments and possible repeals. Further, it was intimated as necessary for Nigeria to undertake a detailed examination of all other applicable laws that would require such treatment. In the end, the Bill adopts two of the foregoing approaches: first, as noted earlier, it directly repeals two current laws that its promulgation will make redundant. ${ }^{172}$ Second, instrumentally, the Bill asserts its supremacy over all laws applicable to activities in any Nigerian maritime zone by accepting their usefulness for its effective implementation. However, it requires that the provisions of all those other laws must be interpreted consistently with its rules. Beyond the foregoing, and without identifying any 
legislation for consequential amendment, the House/Senate Bill uniquely includes a global provision that, 'as may be necessary and determined from time to time,' such amendments shall be made to the relevant laws. ${ }^{173}$ This open-ended flexibility buys time for the appropriate forums to gradually bring applicable laws in line with the requirements of the House/Senate Bill as overarching maritime zones legislation. But on account of entrenched institutional memory and practice, it also creates the possibility that relevant sector legislation, even though interpreted in light of the provisions of the House/Senate Bill, may still be applied inconsistently with the spirit of its implications for required regulatory conduct, particularly regarding disputed matters in maritime zones administration.

\subsubsection{Interpretation}

In addition to repeals and consequential amendments is the benefit of interpretation sections to the modernization of maritime zones legislation. These sections do not exhaust the list of possible items that could be defined for the international ocean law concepts and activities that maritime zones legislations provide for and reflect. In our comparator jurisdictions, the definitions provided for the few items listed ${ }^{174}$ updated the meanings provided for, attached to, or associated with them in preceding national laws applicable to oceans use and administration. This exercise either aligned the meanings of the concepts in relevant national laws with their use in the LOS Convention (and other applicable international instruments, such as International Maritime Organization conventions), or enabled them to reflect the legal nature of the activities they pointed to in light of the LOS Convention's provisions on coastal state rights and jurisdictions in each maritime zone. For instance, Ghana provided no interpretation, presumably because its maritime zones legislation assimilated the language of the Convention in the provisions which claimed its 
maritime zones and the rights and jurisdictions it thereby acquired, so that by implication, interpretation of appropriate concepts and activities provided for in the legislation would be subsumed to their meanings under the Convention (and other relevant international instruments). A variation on the Ghanaian tactic is the legislation of Cyprus, which provided a few Conventionconsistent definitions, but expressly deferred to the Convention's meaning for terms its legislation did not define. Consequently, it accepted the Convention's interpretive authority where its legislation may conflict with the Convention's provisions. ${ }^{175}$

Another approach to interpretation of terms in the maritime domain, which Namibia reflects, is not to define its territory as identified under its Constitution, but rather to expressly make the vesting of any right or power under its maritime zones legislation a matter of constitutional authorization. ${ }^{176}$ Other jurisdictions, such as Jamaica and Cyprus, also identified the geographical extents of their territories as defined or indicated in their constitutions. ${ }^{177}$ Still others, including Canada, India and Kenya, included provisions in their legislations by which to identify and verify the sovereign domains that constituted the basis for their claims to maritime zones, and on the basis of which to vest their jurisdictional rights and powers in regard to the zones. ${ }^{178}$

As noted earlier, no preceding Nigerian legislation has defined the extent of its territory to vest authority for the exercise of jurisdiction in its maritime zones, nor has its 1999 Constitution done so. ${ }^{179}$ Unsurprisingly, the House/Senate Bill does not include 'Nigeria' among the list of items it defines. Like comparator jurisdictions, it aligns interpretations of relevant items in its list with the LOS Convention's provisions. But it breaks new ground by identifying the applicable LOS Convention to include its subsequent amendments and protocols. ${ }^{180}$ In so defining it, when the Bill becomes law, it shall have anticipated and, thus, enabled creative interpretation and application of the maritime zones legislation to potentially ensure that the regulatory and 
administrative regime it establishes remains current with relevant normative and practical developments under the LOS Convention.

\section{Discussion}

The law reform and modernization exercise analysed in this article, the outcome of which is codified in the House/Senate Bill that may become Nigeria's Maritime Zones Act, ${ }^{181}$ offers a number of lessons for comparative oceans law discussion. These lessons speak to aspects of the theoretical underpinnings of the exercise, challenges for developing maritime zones legislation in a major developing coastal State, and benefits for improving domestic legislation for coastal zone and ocean governance in the West African maritime region.

First, in regard to theory, this exercise highlights the need to carefully rationalize the search for guidance from comparator jurisdictions to inform the reform of maritime zones legislation elsewhere. The reasons for choosing the identified jurisdictions have been explained earlier, ${ }^{182}$ an important one of which is the benefits of a common legal tradition. Notwithstanding the usefulness of this factor, in this case, the common law, its influence on crafting the content of context-based legislation transcends understanding concepts common to the national legal systems founded on it. The overarching international ocean law regime in which this exercise is properly situated demands that though essential, commonality of legal tradition must only aid ascertainment of the best practices developed under the international law of the sea regime. Therefore, though it is convenient and useful to scope the appropriate content for the new legislation by first examining legislations from the common law tradition, there cannot be a commitment to ignore comparable legislations in the public law field from jurisdictions rooted in other traditions that also appropriately domesticate the provisions of the Convention in legislation and practice. 
A corollary to the foregoing is the need for the emergent legislation to be structured suitably for its own socio-political and governance context. As earlier explained, beyond legal tradition, it is necessary that comparator jurisdictions must not be selected from only similar constitutional cultures, socio-political and economic conditions, or from one contiguous geographical area. That the ones chosen for this exercise are overwhelmingly rooted within the common law tradition allowed for access to a range of practices that captured different socio-juridical situations in the public law sphere to guide the pursuit of textual clarity and precision. As well, by offering a range of governance and economic variations in social organization and status, the guidance gleaned from them enabled the final legislative product to be readily consistent with the peculiarities of Nigeria's constitutional and general legal system and its own drafting traditions.

Second, the foregoing lesson is reiterated by a related one, namely, that comparison relieves the need to reinvent every proverbial legislative drafting wheel, but without engaging in blind transplants. At the same time, it imposes the discipline to ensure that the advantage of available guidance is converted into context-sensitivity for the derivative work. This is necessary to ensure appropriate response not only to the need for the new legislation, but also to reflect the unique challenges regarding its implementation within the candidate jurisdiction. It has been explained earlier in regard to the Canada Oceans Act that a major objective for enacting it was for its implementation to be directed to achieve the goals of the oceans management strategy set out under it. As such, the Act became the pivotal legislative source of mandates, including the scope of authority of the federal Minister that it identified to lead and coordinate its implementation processes.

The House/Senate Bill does not mandate nor institutionalize a structured implementation process like the Canada Oceans Act. Its inarticulate policy objective, which its long title states and 
its provisions reflect, is to modernize and maximize entitlements and claims to rights and jurisdictions in all maritime zones consistently with the provisions of the LOS Convention. The mandate to exercise those rights and jurisdictions traces to a generic 'Appropriate Authority' via the overarching title and vesting authority of the 'Federal Government of Nigeria or any of its Agencies so designated.' This mandating arrangement resounds in the realities of constitutional power allocation over, and benefits from resource-bearing areas of the federation, including nearshore areas. The legislation implementation challenge this highlights and seems to accommodate is that the institutionalized ocean management regime that will emerge pursuant to the enactment of the Bill into law, must reflect the acceptable balance of power among relevant sector institutions within the federal and state governments, and this, in relation to what socio-economic interests for state and federation are engaged in regard to specific ocean resources development and maritime uses that arise for regulation and benefit as part of the evolution of exploration and exploitation of national ocean areas. ${ }^{183}$

In general, the foregoing reality is not unique to Nigeria. But its theoretical utility in a comparative law discussion focused on law reform and development iterates that a jurisdiction that learns from others to fashion parallel legislation must ensure that the organization of its regulatory arrangements under the contemplated legal scheme reflects the nuances of its constitutional politics. This means that for Nigeria, as distinct from the comparator jurisdictions on which it has leaned to frame its ocean areas legislation, the institutional arrangement it has provided under the House/Senate Bill offers the most feasible political mainstay for potential regulatory effectiveness when the Bill becomes law. This contextual peculiarity cannot be overlooked or belittled as a principle of comparative law analysis if the discipline is to be relevant and able to inspire reform 
and progressive legal development in jurisdictions that need it but may be unable, without comparator precedents, to introduce appropriate changes.

Third, the overall content of the House/Senate Bill highlights the harmonizing impact of comparative analysis for the purpose of law reform. This is particularly useful to domestic implementation and compliance with global legal regimes, in this case, the international law of the sea where rules on subjects of ocean use and regulation that are of common interest to all coastal states converge. In this regard, it is worth reiterating that though Nigeria is a party to the LOS Convention, it is outside its governing authority to the extent that its relevant domestic laws do not reflect the rights and obligations it carries under the Convention. This is because its constitutionally-mandated dualist philosophy requires that the rules of the Convention will become domestic Nigerian law only through legislative transmutation. ${ }^{184}$ By utilizing appropriate comparator legislations to domesticate the Convention's provisions on maritime zones jurisdictions, Nigeria harmonizes its rules on the subject with those of other states that have already done so. This way, once its Bill becomes law, it joins a critical mass of coastal states committed to promoting wider compliance with the Convention in relevant matters, particularly to observe and apply common administrative regulations in regard to the exercise of ocean zones jurisdictions in order to deepen uniformity of practice among them.

A fourth lesson served by the exercise relates to the potential for Nigeria to influence maritime zones legislation reform and development within its regional location in western Africa. On this score, the trio of harmonization, compliance and uniformity of practice consistent with the LOS Convention that the Bill, when it becomes law, makes possible for Nigeria to promote with non-regional coastal states, also gives it the chance to lead in these ways among its neighbouring coastal states in West Africa. Promulgating the Bill into law would offer an example for its 
neighbours that have not yet modernized their maritime zones legislation to follow. ${ }^{185}$ It will also emphasize for all of them, just as for Nigeria itself, that it is necessary to amend other ocean use and regulation-related laws to conform exercise of the mandates they confer to the rules of their maritime zones legislations and, thus, to the LOS Convention.

Nigeria's ability to prod domestic oceans law reform in neighbouring coastal states would positively impact cooperative governance of regional seas, in particular, as regards managing the exploitation of its resources. There are avenues through which Nigeria can channel its influence, and they come through the continuum of issue areas regulated under existing regional regimes. Two such regimes relate to fisheries exploitation, management and conservation, and marine environmental protection. The regional treaties that govern these matters are consistent with the rules of the LOS Convention. However, the practices necessary to ensure compliance with their provisions are not well reflected in the laws of the coastal states. Consequently, their implementation to achieve cooperative objectives is weak, as domestic agencies are not sufficiently empowered to ensure actor compliance with their requirements. ${ }^{186}$ The negative impact of this failure on effective regional ocean governance and its potential benefits for the coastal states has pushed them to accept that each must better domesticate adherence to the LOS Convention and related treaties, and develop practices in conformity with their provisions. ${ }^{187}$ It has been indicated earlier that Nigeria carries weight as a regional power. As such, its leadership, if exemplified in effective implementation of its House/Senate Bill when it becomes law, would enhance the clout it carries to promote this cause among the common and civil law jurisdictions that are its regional coastal neighbours.

Specifically, Nigeria has a direct opportunity to enhance implementation and compliance with global rules on marine environmental protection by having been assigned the leadership to 
coordinate and promote harmonized responses to oil spills and, generally, marine pollution prevention and control under a regional initiative to foster uniform capacity development and resources acquisition and pooling among the coastal states for these purposes. ${ }^{188}$ Nigeria can use this mandate as a platform to promote the adoption of updated principles and rules on marine environmental protection in legislation and practice among its neighbours. A conscientious discharge of this role should also impel Nigeria to reform and develop its relevant legislations so that it could fulfil the duties required to protect its EEZ environment, a matter that is only broadly mandated under the House/Senate Bill. ${ }^{189}$ Effective marine environmental protection is crucial to the viability of marine resources exploration and exploitation in national maritime areas and within the collective regional sea. This reality is acknowledged under the Environmental Policy ${ }^{190}$ of the Economic Community of West African States (ECOWAS), the regional economic integration bloc headquartered in Nigeria. In an Act that accompanies the Policy, member states are obligated to harmonize both their environmental policies and regulatory texts. ${ }^{191}$ The Act has been made part of the constitutive treaty of ECOWAS, and it expressly obligates member states and appropriate institutions of the community to implement its provisions. ${ }^{192}$ This creates a clear legal basis for the ECOWAS Parliament Committee on Agriculture, Environment, Water Resources and Rural Development to proactively develop harmonizing policy and legislation. Significantly, the Committee's specified mandates include attention to ocean governance and the exploitation and management of its resources. ${ }^{193}$ If the Committee and Parliament fashion regional policy and law for the sector, it would catalyse parallel national policy and legal evolution. Nigeria could utilize its political and economic weight to influence and promote this cause through these regional forums. 
Fifth, a natural corollary to the potential positive impact that the reform of Nigeria's maritime zones legislation could have in West Africa arises in the context of the close coordination of ocean resources exploitation and marine environmental protection regulation between the western and eastern African regional seas regimes. Progress in ocean law reform in the West, nationally and regionally, influences developments in the East, and vice versa. This is not only on account of the role of the United Nations agencies that coordinate implementation and administration of the regimes in both regions. This mutually beneficial exchange is also boosted by the decision of the continental political organization, the African Union, to promote the emergence of robust maritime governance across Africa's ocean regions through systematic evolution of effective management over ocean uses and resources development consistently with the rules of the LOS Convention. Among others, the African Union plans to use the regional economic communities to promote this goal. Its strategy requires that to spur development, the regional communities must bridge the economic-environment divide in the maritime sector because this is pivotal to the success of regional and continental economic growth and integration. ${ }^{194}$ In this regard, therefore, the continental strategy underlines the positive mutual impacts and utility that legal reform and development for national and regional ocean areas administration in either region would have across both regions.

\section{Conclusion}

In sum, the reform of Nigeria's maritime zones legislation, as discussed in this article, first illustrates the usefulness of comparative analysis of legal instruments for purposes of such an exercise. Second, it highlights the benefits this exercise may hold for any jurisdiction, whatever its legal tradition. Third, it practically demonstrates that the resulting legislative reform can radiate 
into comparable law reform and, thus, legal harmonization for oceans governance in Africa's ocean regions where littorals share comparable degrees of need for the kind of reform that Nigeria

has undertaken in its prospective Maritime Zones Act.

${ }^{1}$ United Nations Convention on the Law of the Sea, adopted 10 December 1982, entered into force 16 November 1994, 1833 UNTS 397 (LOS Convention).

${ }^{2}$ DOALOS, Current Status of the Convention, <http://www.un.org/Depts/los/reference_files/status2010.pdf $>$.

${ }^{3}$ LOS Convention arts. 3, 33, 57, 76 and 303.

4 Case Concerning the Land and Maritime Boundary between Cameroon and Nigeria (Cameroon v Nigeria: Equatorial Guinea Intervening) [2002] ICJ Rep 303.

${ }^{5}$ In November 2002, the Cameroon-Nigeria Mixed Commission was established under the chairmanship of the Special Representative of the Secretary General for West Africa to consider issues arising from the ICJ decision, including demarcation of the land border and delimitation of the maritime boundary. See Cameroon-Nigeria: recommendations of United Nations Mixed Commission, in: D.A. Colson et al (Eds.), International Maritime Boundaries, volume VI, Martinus Nijhoff, 2011, pp. 4251-4255. On 26 April 2013, the thirty-first meeting of the Commission was convened in Yaoundé under the auspices of the United Nations Office for West Africa (UNOWA) <http://unowa.unmissions.org/Default.aspx?tabid=804>. Nigeria also established a National Boundary Commission under its National Boundary Commission $\quad$ (Establishment) 2006 <http://www.placng.org/lawsofnigeria/node/218>.

${ }^{6}$ Treaty on the Maritime Boundary Delimitation between The Federal Republic of Nigeria and The Republic of Benin, Abuja (4 August 2006) in: D.A. Colson et. al., (n 5) pp. 4266-4269.

7 Treaty Between the Federal Republic of Nigeria and the Republic of Equatorial Guinea Concerning their Maritime Boundary, adopted 23 September 2000, entered into force 3 April 2002, <http://www.un.org/Depts/los/LEGISLATIONANDTREATIES/PDFFILES/TREATIES/NGA-

GNQ2000MB.PDF>; Treaty Between Equatorial Guinea and Nigeria on Joint Exploration of Crude Oil, especially at the Zafiro-Ekanga Oil Field Located in the Maritime Boundary of both Countries, 3 April 2002 (unpublished).

${ }^{8}$ Treaty between the Federal Republic of Nigeria and the Democratic Republic of São Tomé and Príncipe on the Joint Development of Petroleum and other Resources in respect of Areas of the Exclusive Economic Zone of the two States, 21 February 2001, entered into force 16 January 2003, in: D.A. Colson et al. (Eds.), International Maritime Boundaries, volume V, Matinus Nijhoff, 2005, pp. 3649-82. A substantial concern was certainty of maritime boundaries for the purposes of offshore oil licensing blocks in a promising area. See T. Daniel, African Maritime Boundaries, in: D.A. Colson et.al., ibid. pp. 3429, 3432-3434. The maritime boundary between the two countries has not yet been delimited. 9 The submission was made on 7 May 2009. UN Continental Shelf Notification, 11 May 2009, <http://www.un.org/Depts/los/clcs_new/submissions_files/nga38_09/nga_clcs38_2009e.pdf>. Nigeria was the 38th State to make such a submission.

${ }^{10}$ Nigeria's submission is one in a considerable list of submissions currently under consideration. For a recent indication, see Progress of work in the Commission on the Limits of the Continental Shelf, Statement by the Chair, Corrigendum Paragraph 3(f), Thirty-fourth Session, New York 27 January-14 March 2014, (19 May 2014) CLCS/83/Corr.1 <http://www.un.org/depts/los/clcs_new/commission_documents.htm>. As of February 2013, it appears that funding for the extended continental shelf initiative was running out, prompting a motion by Senator Emmanuel Bwacha in the Senate on 14 February 2013 <http://www.channelstv.com/home/2013/02/14/senate-urgesfg-to-fund-continental-shelf-project/>.

${ }^{11}$ Data on the geographical size of Nigeria's extended shelf claim is not indicated. However, the cartographical information and representation of the legitimate area arising from application of the relevant provisions of the LOS Convention indicates that it is not particularly large, given that the claim is confined to the western portion of its coastal length where it is further constrained by the claims of its three neighbors further west, namely, Benin, Togo and Ghana. See Executive Summary: A Submission of Data and Information on the Outer Limits of the Continental Shelf of the Republic of Nigeria Pursuant to Part VI of and Annex II to the United Nations Convention on the Law of the Sea - Submission to the Commission on the Limits of the Continental Shelf through the Secretary-General of the 


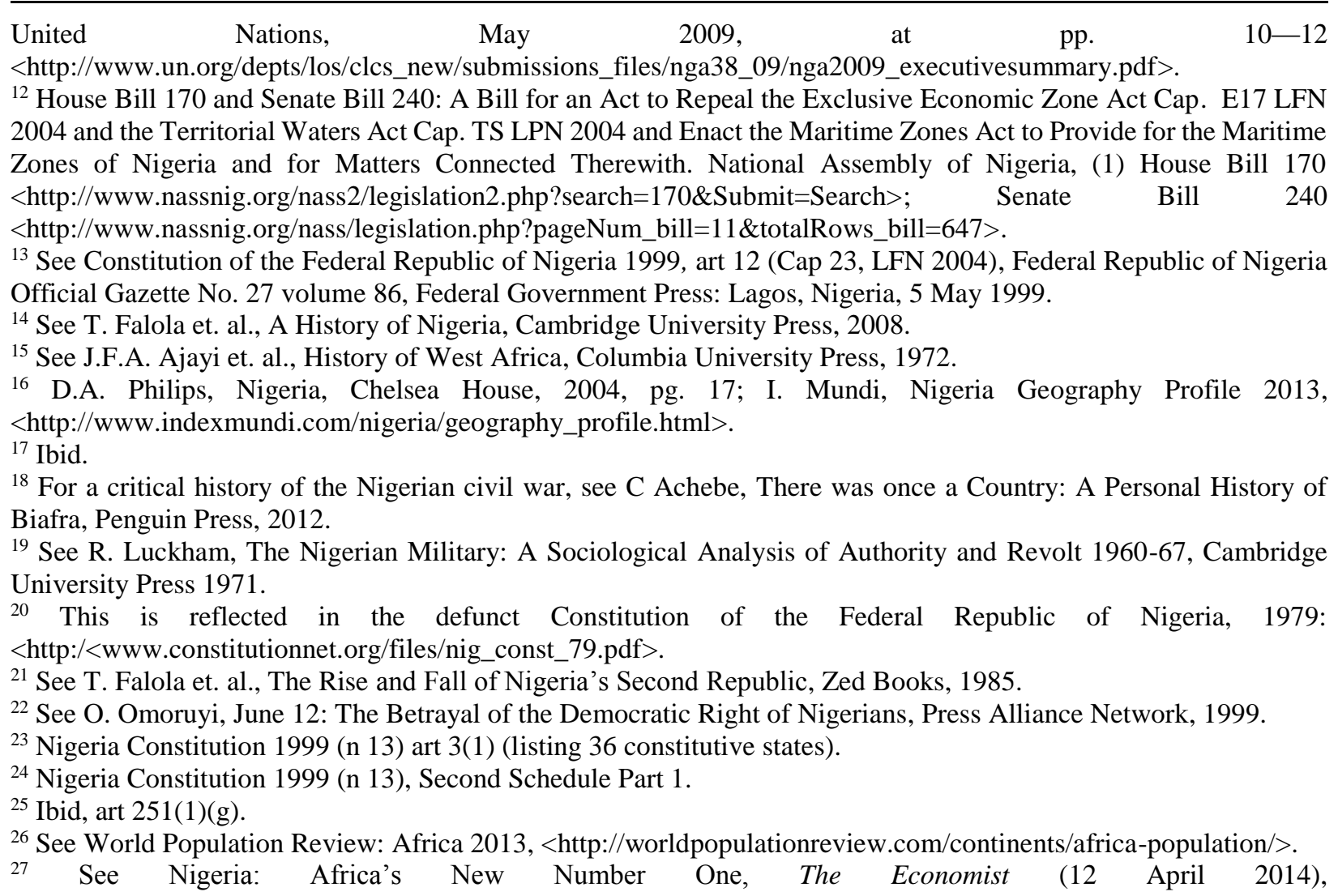
<http://www.economist.com/news/leaders/21600685-nigerias-suddenly-supersized-economy-indeed-wonder-so-areits-still-huge>. See also PWC Economics, The World in 2050: The BRICS and beyond - prospects, challenges and opportunities, January 2013, <http://www.pwc.com/en_GX/gx/world-2050/assets/pwc-world-in-2050-reportjanuary-2013.pdf>.

${ }^{28}$ See (n 18) and accompanying text.

${ }^{29}$ See West Africa Gateway (Sahel and West Africa Club), <http://www.westafricagateway.org/west-africa/countryprofiles/nigeria>.

${ }^{30}$ Nigeria Constitution 1999 (n 13) art 162(2).

${ }^{31}$ For example, 8 littoral states dragged the Federal Government to the Supreme Court seeking a declaration that each of their territories extends beyond the low-water mark onto the territorial water and even onto the continental shelf and the exclusive economic zone, and that pursuant to art 162(2) of the 1999 Constitution, they are entitled to no less than 13 per cent of revenue derived from both onshore and offshore natural resources (oil). The Federal Government took the converse position and insisted that natural resources located within the continental shelf of Nigeria cannot be credited as derived from any state of the Federation for revenue allocation purposes. The Supreme Court held that the seaward boundary of a littoral state within Nigeria, for the purpose of calculating the amount of revenue accruing to the Federation Account directly from any natural resources derived from that state pursuant to the constitutional provision on derivation, is the low water mark of the land surface thereof, or in the case of a state with an archipelago of islands, the boundary is the seaward limits of inland waters within that state (there is only one state under this category). See generally Attorney General of the Federation v. Attorney General of Abia State and 35 Ors (No. 2) [2002] 6 NWLR (Pt 764) 542.

${ }^{32}$ See (n 4) with accompanying text. On the contested legal and confrontation-riddled background to the dispute, see N.J. Bekong, International dispute settlement: Land and maritime boundary between Cameroon and Nigeria - Origin of the dispute and provisional measures, African J. Intl. and Comp. L. 9 (1997) 287-310; O.O. Sholanke, Delimiting the territorial sea between Nigeria and Cameroon: A rational approach, I.C.L.Q. 42 (1993) 398-411.

${ }^{33}$ See Commission on the Limits of the Continental Shelf, Scientific and technical guidelines of the Commission on the Limits of the Continental Shelf, 13 May 1999, CLCS/11 (with corrigenda and annexes)<http://www.un.org/depts/los/clcs_new/commission_documents.htm\#Guidelines>.

${ }^{34}$ First is the Convention on the Territorial Sea and the Contiguous Zone, done at Geneva 29 April 1958, entered into force 10 September 1964, 7477 UNTS 206. Nigeria succeeded to it on 26 June 1961. Second is the Convention on the 
High Seas, done at Geneva 29 April 1958, entered into force 30 September 1962, 6465 UNTS 82. Nigeria succeeded to it on 26 June 1961 and it became effective for it on 30 September 1962. Third is the Convention on Fishing and Conservation of the Living Resources of the High Seas, done at Geneva 29 April 1958, entered into force 20 March 1966, 8164 UNTS 286. Nigeria succeeded to it on 26 June 1961. Fourth is the Convention on the Continental Shelf, done at Geneva 29 April 1958, entered into force 10 June 1964, 7302 UNTS 312. Nigeria acceded to this on 28 April 1971 and it became effective for it on 28 May 1971.

35 The Territorial Waters Act 1967, Cap T5 LFN 2004, as amended and consolidated: <http://www.placng.org/lawsofnigeria/node/399>. Under section 1 of this Act, Nigeria claims a breadth of 12 nautical miles as territorial waters, retreating from the original claim of 30 nautical miles. The Petroleum Act 1969, Cap P10 LFN 2004, explains under section 15(1) that Nigeria's continental shelf includes submarine areas that lie to a depth not greater than 200 meters, or where the natural resources are capable of exploitation at any depth below the surface of the sea, but excludes those areas that lie below territorial waters: <http://www.babalakinandco.com/resources/lawsnigeria/LAWS/90350petroleum\%20act.htm\#SUBSIDIARY>.

36 Exclusive Economic Zone Act 1978, Cap E17 LFN 2004, <http://www.un.org/Depts/los/LEGISLATIONANDTREATIES/PDFFILES/NGA_1978_Decree.pdf>; $\quad$ and $\langle$ http://www.placng.org/lawsofnigeria/node/97>.

${ }^{37}$ Convention on the Continental Shelf (n 34) art 1; compare with second reference in (n 35).

${ }^{38}$ LOS Convention (n 1) art 311(1).

${ }^{39}$ Convention on Territorial Sea and Contiguous Zone (n 34) art 24; LOS Convention (n 1) art 33.

${ }^{40}$ These included the following drafts considered by the research team: An Act to repeal the Exclusive Economic Zone Act Cap. E17 LFN 2004 and the Territorial Waters Act Cap. T5 LFN 2004 and Enact the Maritime Zones Act to, among other things, Determine the Maritime Zones of Nigeria and for Matters Connected Therewith (Second Draft Bill, received on 30 October 2006); An Act to Repeal the Exclusive Economic Zone Act Cap. E17 LFN 2004 and the Territorial Waters Act Cap. T5 LFN 2004 and Enact the Maritime Zones Act to, among other things, Determine the Maritime Zones of Nigeria and for Matters Connected Therewith (Third Draft Incorporating first and second drafts, received on 3 November 2006); An Act to Repeal the Exclusive Economic Zone Act Cap. E17 LFN 2004 and the Territorial Waters Act Cap. T5 LFN 2004 and Enact the Maritime Zones Act to Provide for the Maritime Zones of Nigeria and for Matters Connected Therewith [Fourth Draft Incorporating Nigerian Drafts and Recommendations of the Investigators/Consultants from Dalhousie University, Halifax, Canada] (Fourth Draft Bill, received on 24 November 2006, on file with authors).

${ }^{41}$ This is consistent with the pacta sunt servanda principle of international treaty law reflected in art 18 of the Vienna Convention on the Law of Treaties, adopted 22 May 1969, entered into force 27 January 1980, 1155 UNTS 331, reprinted in I.L.M. 8 (1969) 679. Any State Party which disputes the interpretation given to the LOS Convention by another State Party has the right to utilize the Convention's dispute settlement procedures in Part XV: LOS Convention (n 1) art 279.

${ }^{42}$ The United Nations Department on Oceans and the Law of the Sea regularly publishes such protests in the issues of the Law of the Sea Bulletin: <http://www.un.org/Depts/los/doalos_publications/los_bult.htm>. As well, through its 'freedom of navigation' program, the United States protests claims that it considers unwarranted under the international legal regime of the seas. For these operations between 1993-2010 in the waters of various coastal states and the legal bases for their justification, see S. Groves, Accession to the U.N. Convention on the Law of the Sea is unnecessary to secure U.S. navigational rights and freedoms, The Heritage Foundation Backgrounder No. 2599 (24 August 2014) 1-38 at 6,31-38. Also, see in particular J.A. Roach et. al., Excessive Maritime Claims third ed., Martinus Nijhoff, 2012; and J. Kraska, Maritime Power and the Law of the Sea: Expeditionary Operations in World Politics, Oxford University Press, 2011, Ch 3, 4, 6 and Annex I.

${ }^{43}$ For literature highlighting issues in the comparative approach, see for example J. Hill, Comparative law, law reform and legal theory, Oxford J. Leg. Studies 9 (1989) 101-115; G. Dannemann, Comparative law: study of similarities or differences?, in: The Oxford Handbook on Comparative Law, OUP, 2006, pp. 383-419; E. Orücü, Developing comparative law, in: E. Orücü, D. Nelken (Eds.), Comparative Law: A Handbook, Hart Publishing, 2007, pp. 43-65. On the use of the comparative law approach in a public law context, see J. Bell, Comparing public law, in: A. Harding, E. Orücü (Eds.), Comparative Law in the $21^{\text {st }}$ Century, Kluwer Academic Publishers, 2002, pp. 235-247.

${ }^{44}$ Oceans Act 1996

<http://www.un.org/Depts/los/LEGISLATIONANDTREATIES/PDFFILES/CAN_1996_Act.pdf〉.

${ }^{45}$ The Territorial Waters, Continental Shelf, Exclusive Economic Zone and Other Maritime Zones Act 1976

<http://www.un.org/Depts/los/LEGISLATIONANDTREATIES/PDFFILES/IND_1976_Act.pdf>.

${ }^{46}$ Maritime Zones Act 1994

<http://www.un.org/Depts/los/LEGISLATIONANDTREATIES/PDFFILES/ZAF_1994_Act.pdf>. 
${ }^{47}$ Archipelagic Waters and Maritime Jurisdiction Act 1993

<http://www.un.org/Depts/los/LEGISLATIONANDTREATIES/PDFFILES/BHS_1993_37.pdf>.

${ }^{48}$ Maritime Areas Act 1992

<http://www.un.org/Depts/los/LEGISLATIONANDTREATIES/PDFFILES/BLZ_1992_MAA.pdf>.

${ }^{49}$ Maritime Zones (Delimitation) Law 1986

<http://www.un.org/Depts/los/LEGISLATIONANDTREATIES/PDFFILES/GHA/_1986_Law.pdf>.

${ }^{50}$ Territorial Sea and Exclusive Economic Zone Act 1977

<http://www.un.org/Depts/los/LEGISLATIONANDTREATIES/PDFFILES/NZL_1980_Act.pdf〉.

${ }^{51}$ Maritime Zones Act

<http://www.un.org/Depts/los/LEGISLATIONANDTREATIES/PDFFILES/KEN_1989_Maritime.pdf>.

52 Territorial Sea and Exclusive Economic Zone of Namibia Act 1990

<http://www.un.org/Depts/los/LEGISLATIONANDTREATIES/PDFFILES/NAM_1990_Act.pdf>, as amended by

Territorial Sea and Exclusive Economic Zone of Namibia Amendment Act, 1991

<http://www.un.org/Depts/los/LEGISLATIONANDTREATIES/PDFFILES/NAM_1991_Act.pdf>.

${ }^{53}$ Territorial Sea and Exclusive Economic Zone Act, 1989

<http://www.un.org/Depts/los/LEGISLATIONANDTREATIES/PDFFILES/TZA_1989_Act.pdf>.

${ }^{54}$ Maritime Zones Act 1999

<http://www.un.org/Depts/los/LEGISLATIONANDTREATIES/PDFFILES/WSM_1999_MaritimeZ.pdf>.

${ }^{55}$ This included Cyprus whose relatively modern legislation employs more than one statute to claim maritime zones and jurisdictions. Contiguous Zone Law of 2004

<http://www.un.org/Depts/los/LEGISLATIONANDTREATIES/PDFFILES/cyp_2004_cz_proclamation.pdf>;

Exclusive Economic Zone Law of 2004

<http://www.un.org/Depts/los/LEGISLATIONANDTREATIES/PDFFILES/cyp_2004_eez_proclamation.pdf>.

${ }^{56}$ Exclusive Economic Zone Act 1991

$<$ http://www.un.org/Depts/los/LEGISLATIONANDTREATIES/PDFFILES/JAM_1991_Act.pdf〉; Maritime Areas Act 1996 <http://www.un.org/Depts/los/LEGISLATIONANDTREATIES/PDFFILES/JAM_1996_Act.pdf>.

${ }^{57}$ Exclusive Economic Zone Act, 1984

<http://www.un.org/Depts/los/LEGISLATIONANDTREATIES/PDFFILES/MYS_1984_Act.pdf〉.

${ }^{58}$ Territorial Waters and Maritime Zones Act, 1976

<http://www.un.org/Depts/los/LEGISLATIONANDTREATIES/PDFFILES/PAK_1976_Act.pdf>.

${ }^{59}$ National Seas Act 1977

<http://www.un.org/Depts/los/LEGISLATIONANDTREATIES/PDFFILES/PNG_1977_Act7.pdf>.

${ }^{60}$ The Maritime Zones Act, 1981

<http://www.un.org/Depts/los/LEGISLATIONANDTREATIES/PDFFILES/VUT_1981_Act.pdf〉.

${ }^{61} R \mathrm{v}$ Keyn (The Franconia) [1876] 2 Ex D 63, the reputed judicial origin of the doctrine that English municipal courts would enforce rules of international law in common with other nations provided they were adopted by England, and also that they are not inconsistent with domestic statutory or judicial decisions on the question in issue. While the evolution of the application of this dualist doctrine on the national-international law relations would have applied to Nigeria up to independence in 1960, since then, no post-independence Nigerian Constitution ever made any direct provision on this question. Consequently, by default, the incorporation doctrine governs Nigerian practice in regard to customary international law (the rule in $R \vee$ Keyn). As well, it is pointed out above (n 13 with text) that treaties must be adopted as statutes before they could be implemented in Nigeria. See also A. Oyebode, International Law and Politics: An African Perspective, Bolabay Publications, 2003, pg. 47.

${ }^{62}$ The Federal High Court has plenary jurisdiction over civil, criminal and fiscal matters and also in regard to issues involving questions of international law. Subject to the scope of its jurisdiction, state High Courts have civil and criminal jurisdiction in regard to matters originating within each state. See Nigerian Constitution 1999 (n 13) art 251, 252 and 272. The types of disputes over jurisdiction and entitlement that this engenders in regard to marine use and benefit are exemplified by the case noted above (n 31$)$.

${ }^{63}$ Canada Oceans Act (n 44) Preamble.

${ }^{64}$ Ghana Maritime Zones Delimitation Act 1986 (n 49) Preamble.

${ }^{65}$ Ibid., sections 1-7. Cyprus also reflects this approach in its 2004 legislations on the Contiguous Zone and the Exclusive Economic Zone respectively (n 55).

${ }^{66}$ The variation essentially consists in the employment of sub-titles. See Territorial Sea and Exclusive Economic Zone of Namibia Act 1990 (n 52) and South Africa Maritime Zones Act 1994 (n 46).

${ }^{67}$ Bahamas Archipelagic Waters and Maritime Jurisdiction Act 1993 (n 47) sections 5-6 and 11-13.

${ }^{68}$ Jamaica Maritime Areas Act 1996 (n 56) sections 16-17. 
${ }^{69}$ Jamaica Exclusive Economic Zone Act 1991 (n 56) sections 3-8.

${ }^{70}$ Ibid., sections 9, 11, 20-21.

${ }^{71}$ Ibid., sections 10, 12-19.

${ }^{72}$ See the legislations of these countries ( $\mathrm{n} 48,51,50$ and 53) respectively.

${ }^{73}$ A typical outline of such legislation is as follows: Part I: Title or Short Title and Interpretation or Definitions; Part II: Internal Waters and/or Territorial Sea and/or Archipelagic Waters (among others, the claims here make provisions relating to establishment of baselines, outer limits of territorial waters, rights of the coastal state and foreign states in the waters claimed); Part III: Contiguous Zone, including the specific enforcement jurisdictions within; Part IV: EEZ and Continental Shelf, including the sovereign rights and jurisdictions in those zones and related provisions; Part V: Miscellaneous (provisions here include allocation of regulatory power for the administration of the statute, identification of institutional responsibilities, transitional provisions (i.e., repeal and amendments, etc.).

${ }^{74}$ Kenya Maritime Zones Act 1989 (n 51) sections 4-13; Tanzania Territorial Sea and Exclusive Economic Zone Act 1989 (n 53) sections 12 and 19.

${ }^{75}$ Kenya Maritime Zones Act 1989 (n 51) sections 9-11.

${ }^{76}$ Tanzania Territorial Sea and Exclusive Economic Zone Act 1989 (n 53) sections 13-18.

${ }^{77}$ Belize Maritime Areas Act 1992 (n 48) Parts V and VI.

${ }^{78}$ New Zealand Territorial Sea and Exclusive Economic Zone Act 1977 (n 50) sections 10-28.

${ }^{79}$ Canada Oceans Act (n 44) Preamble.

${ }^{80}$ Ibid., sections $4-18$ and $28-36$.

${ }^{81}$ Ibid., sections $4-22$ and $37-39$.

82 Ibid., sections $23-27$ and $40-52$.

${ }^{83}$ The legislative scheme is as follows: Baselines and delineation; Internal Waters; Territorial waters; Jurisdiction in respect of offences committed in territorial waters; Restriction on trial of persons other than Nigerian citizens for offences committed in territorial waters; Contiguous zone; Archaeological and Historical Objects; Jurisdiction and penalty; EEZ; Sovereign Rights and jurisdiction for the Exploration, Exploitation, etc.; Exclusive right of jurisdiction as regards establishment and use of islands, installations, etc.; Prevention and enforcement in the EEZ; Delineation and Delimitation of the Continental Shelf of Nigeria; Sovereign Right and Jurisdiction for the Exploration, Exploitation, etc. of the Continental Shelf; Application of Criminal and Civil Laws In the Maritime Zones; Offences Committed in Designated Areas; Penalties; Laying of cables and pipes on the continental shelf; Power to Make Regulations; Repeal; Supremacy of Act; Consequential Amendment of Maritime Related Legislations in Nigeria; Interpretation.

${ }^{84}$ By virtue of articles 1 and 2 of the Constitution of the Federal Republic of Nigeria 1999 (n 13), Nigeria's geographical territory, including its maritime areas, is assumed. Within that territory, no laws shall prevail over the Constitution and no government shall be instituted except as envisaged by the Constitution.

${ }^{85}$ Art. 4(2) of the Constitution of the Republic of Ghana provides as follows: "Parliament may by law provide for the delimitation of the territorial sea, the contiguous zone, the exclusive economic zone and the continental shelf of Ghana." See Constitution of the Republic of Ghana, 1992, being a Schedule to the Constitution of the Fourth Republic of Ghana (Promulgation) Law 1992, P.N.D.C.L. $<$ http://www.judicial.gov.gh/constitution/chapter/chap_25.htm>.

86 "The national territory comprises the Philippine archipelago, with all the islands and waters embraced therein, and all other territories over which the Philippines has sovereignty or jurisdiction, consisting of its terrestrial, fluvial and aerial domains, including its territorial sea, the seabed, the subsoil, the insular shelves, and other submarine areas. The waters around, between, and connecting the islands of the archipelago, regardless of their breadth and dimensions, form part of the internal waters of the Philippines." Constitution of the Republic of the Philippines 1987, art 1: <http://www.gov.ph/constitutions/the-1987-constitution-of-the-republic-of-the-philippines/>.

${ }^{87}$ See Constitution of the Federal Republic of Nigeria 1999 (n 13) art 44(3).

${ }^{88}$ Petroleum Act 1969 (n 35) section 1(2).

${ }^{89}$ Minerals and Mining Act 1999, Cap M12 LFN 2004, repealed and replaced by the Nigerian Minerals and Mining Act 2007, (2007 No 50), retains and provides in section 1(1): "The entire property in and control of all minerals, in, under or upon any land in Nigeria, its contiguous continental shelf and all rivers, streams and watercourses throughout Nigeria, any area covered by its territorial waters or constituency and the Exclusive Economic Zone is and shall be vested in the Government of the Federation for and on behalf of the people of Nigeria." The current legislation is at <http://www.placng.org/lawsofnigeria/node/360>.

${ }^{90}$ House/Senate Bill (n 12) sections 13(1)-(2) and 14(1).

${ }^{91}$ Ibid., sections 13(1) and 14(1).

${ }^{92}$ LOS Convention (n 1), art 311(1). 
${ }^{93}$ Petroleum Act (n 35) section 15 defines the continental shelf as 'the sea-bed and subsoil of those submarine areas adjacent to the coast of Nigeria the surface of which lies at a depth no greater than two hundred metres (or, where its natural resources are capable of exploitation, at any depth) below the surface of the sea, excluding so much of those areas as lies below the territorial waters of Nigeria.'

${ }^{94}$ House/Senate Bill (n 12) section 21.

${ }^{95}$ LOS Convention (n 1) art 5, 9-14.

${ }^{96}$ Belize Maritime Areas Act 1992 (n 48) section 4(5); South Africa Maritime Zones Act 1994 (n 46) section 2(5).

${ }^{97}$ LOS Convention (n 1) art 7.

${ }^{98}$ Ibid., art 10. This means that Nigeria could utilize closing lines for bays where the distance between the natural entrance points does not exceed 24 nautical miles.

${ }^{99}$ LOS Convention (n 1) art 7 compared to art 10.

${ }^{100}$ New Zealand Territorial Sea and Exclusive Economic Zone Act 1977 (n 50) section 6; Papua New Guinea National Seas Act 1977 (n 59) Schedule 1 section 3; Western Samoa Maritime Zones Act 1999 (n 54) section 7; Vanuatu Maritime Zones Act 1981 (n 60) section 1.

${ }^{101}$ LOS Convention (n 1) art 16. Other jurisdictions, example Belize, tasked the Minister with the preparation of charts: The Belize Maritime Areas Act 1992 (n 48) section 14.

${ }^{102}$ House/Senate Bill (n 12) sections 1(1)-(3).

${ }^{103}$ Ibid., sections 1(4)-(5).

${ }^{104}$ National Inland Waterways Act, No 13 of 1997 LFN, (also designated National Inland Waterways Authority Act) Section 29 defines baseline as 'the low water mark along the coast of Nigeria.' The Act is available at <http://www.nigeria-law.org/National\%20Inland\%20Waterways\%20Decree.htm>; and

$<$ http://www.placng.org/lawsofnigeria/node/454>.

105 Interpretation Act 1964, Cap 123 LFN 2004, section 18(1) <http://www.placng.org/lawsofnigeria/node/133>; Coastal and Inland Shipping (Cabotage) Act (CISCA), No 5 of 2003, Cap C51 LFN 2004, <http://www.placng.org/lawsofnigeria/node/82>. Section 2 of the latter affirms the definition of inland waters provided under the Inland Waterways Act (which is reproduced at n 106 below). The Federal Environmental Protection Agency Act (FEPAA) 1988, as amended, Cap F10 LFN 2004, <http://www.placng.org/lawsofnigeria/files/F10.pdf>, provides a generic definition of waters of Nigeria which does not specifically include internal waters. The definition under section 41 refers to 'all water resources in any form, including atmospheric, surface and subsurface, and underground water resources where the water resources are interState, or in the Federal Capital Territory, territorial waters, Exclusive Economic Zone or in any other area under the jurisdiction of the Federal Government.'

${ }^{106}$ National Inland Waterways [Authority] Act (n 104). In section 29, it defines 'inland waterways' to include 'all waterways, rivers, creeks, lakes, tidelands, lagoons below the low water baseline,' whereas 'internal water' refers to 'all waters on the landward side of the baseline of the territorial sea.'

${ }^{107}$ Interpretation Act (n 105) in section 18(1), defines 'inland waters' as including 'all rivers, creeks and lagoons inside the river bars of Nigeria.' It should be noted that in Article 318(4), the Constitution of the Federation of Nigeria 1999 (n 13), endorses the application of the Interpretation Act to the interpretation of all laws in Nigeria, including the Constitution.

${ }^{108}$ House/Senate Bill (n 12) section 2: 'The internal waters of Nigeria for all purposes, consist of the waters on the landward side of the straight baselines and closing lines from which the breadth of the territorial waters of Nigeria is measured.'

${ }^{109}$ Canada Oceans Act 1996 (n 44) section 6; Belize Maritime Areas Act 1992 (n 48) section 5; South Africa Maritime Zones Act 1994 (n 46) section 3(1)(a)(b); Namibia Territorial Sea and EEZ Act 1990 (n 52) section 3.

110 House/Senate Bill (n 12) section 3(2). For the practice in other jurisdictions, see Ghana Maritime Zones Delimitation Law 1986 (n 49) section 2; India, Territorial Waters, Continental Shelf, Exclusive Economic Zone and other Maritime Zones Act 1976 (n 45) section 3(1); South Africa Maritime Zones Act 1994 (n 46) section 4(2).

${ }^{111}$ LOS Convention (n 1) art 17-20.

112 Ibid., art 21-26. This is safeguarded in the House/Senate Bill (n 12) section 3(3).

${ }^{113}$ LOS Convention (n 1) art 21(4). Nigeria has not gone as far as other States in legislating innocent passage in detail, but its provision in section3(3) of the Bill is similar to that in the South Africa Maritime Zones Act 1994 (n 46) section 4(3). For examples of detailed regulation, see: Jamaica Maritime Areas Act 1996 (n 56) sections 13 and 18; Belize Maritime Areas Act 1992 (n 48) sections 11-13.

${ }^{114}$ House/Senate Bill (n 12) section 5(1). 
${ }^{115}$ According to art 27(1) of the LOS Convention (n 1), criminal jurisdiction on board a foreign ship should not be exercised by the coastal State 'to arrest any person or to conduct any investigation in connection with any crime committed on board the ship during its passage, save only in the following cases:

(a) if the consequences of the crime extend to the coastal State;

(b) if the crime is of a kind to disturb the peace of the country or the good order of the territorial sea;

(c) if the assistance of the local authorities has been requested by the master of the ship or by a diplomatic agent or consular officer of the flag State; or

(d) if such measures are necessary for the suppression of illicit traffic in narcotic drugs or psychotropic substances.'

${ }^{116}$ LOS Convention (n 1) art 15.

${ }^{117}$ House/Senate Bill (n 12) section 3(4). For other state practice, see Belize Maritime Areas Act 1992 (n 48) section 3(4); Namibia Territorial Sea and EEZ Act 1990 (n 52) section 5; Tanzania Territorial Sea and EEZ Act 1989 (n 53) section 2(2).

118 House/Senate Bill (n 12) section 3(5). For similar practice, see Bahamas Act Respecting the Territorial Sea, Archipelagic Waters, Internal Waters and the Exclusive Economic Zone 1993 (n 47) section14.

${ }^{119}$ See observations made by A. Chircop et. al., The maritime zones of East African states in the Law of the Sea: Benefits gained, opportunities missed, African J. of Intl. and Comp. L. 16 (2008) 121-151.

${ }^{120}$ LOS Convention (n 1) art 33.

${ }^{121}$ Chircop (n 119) 132-133.

${ }^{122}$ House/Senate Bill (n 12) section 6. The practice of Canada (Oceans Act 1996 (n 44) section 10), South Africa (Maritime Zones Act 1994 (n 46) section 5), Jamaica (Maritime Areas Act 1996 (n 56) section 20) and Cyprus (Contiguous Zone Law 2004 (n 55)) were considered.

${ }^{123}$ LOS Convention (n 1) art 303.

${ }^{124}$ South Africa Maritime Zones Act 1994 (n 46) section 6; Cyprus Contiguous Zone Law 2004 (n 55) sections 4-5.

${ }^{125}$ House/Senate Bill (n 12) section 7.

${ }^{126}$ House/Senate Bill (n 12) sections 6-8.

127 The key provision was the following: 'Without prejudice to the Territorial Waters Decree 1967, the Petroleum Decree 1969 or the Sea Fisheries Decree 1971, sovereign and exclusive rights with respect to the exploration and exploitation of the natural resources of the seabed, subsoil and superjacent waters of the Exclusive Zone shall vest in the Federal Republic of Nigeria and such rights shall be exercisable by the Federal Military Government or by such Federal Commissioner or agency as that Government may from time to time designate in that behalf either generally or in any special case.' Exclusive Economic Zone Act (n 36) section 2(1).

${ }^{128}$ Ibid., sections 3-4.

${ }^{129}$ LOS Convention (n 1) art 56(1)(b)(ii) and (iii).

${ }^{130}$ In particular: Canada Oceans Act 1996 (n 44) section 14; Cyprus Exclusive Economic Zone Law 2004 (n 55) section 4(1). Jamaica Exclusive Economic Zone Act 1991 (n 56) section 4 was considered. However, its association of jurisdiction to authorize recovery of archaeological and historical objects with jurisdiction over marine scientific research in the EEZ is not provided in the LOS Convention and is consequently controversial. South Africa Maritime Zones Act 1994 (n 46) section 7(2) included a more general provision which is not aligned with the text of the LOS Convention and was consequently not considered a useful model.

${ }^{131}$ House/Senate Bill (n 12) section 10(1).

${ }^{132}$ Ibid., section 10(3).

${ }^{133}$ Ibid., section 11.

${ }^{134}$ Petroleum Act 1969 (n 35) in section 15(1) defines the continental shelf to mean 'the sea-bed and subsoil of those submarine areas adjacent to the coast of Nigeria the surface of which lies at a depth no greater than two hundred metres (or, where its natural resources are capable of exploitation, at any depth) below the surface of the sea, excluding so much of those areas as lies below the territorial waters of Nigeria.'

${ }^{135}$ South Africa Maritime Zones Act 1994 (n 46) section 8(1); Namibia Territorial Sea and Exclusive Economic Zone Act 1990 (n 52) section 6(1).

${ }^{136}$ South Africa Maritime Zones Act 1994 (n 46) section 8(2).

${ }^{137}$ Canada Oceans Act 1996 (n 44) section 17; Jamaica Maritime Areas Act 1996 (n 56) section 21.

138 Jamaica Maritime Areas Act 1996 (n 56) section 21(1) and section 6 regarding archipelagic baselines.

${ }^{139}$ Canada Oceans Act 1996 (n 44) section 25.

${ }^{140}$ House/Senate Bill (n 12) section 13(2).

${ }^{141}$ LOS Convention (n 1) art 76(5).

${ }^{142}$ Ibid., arts 76(9) and 84. 
143 Belize Maritime Areas Act 1992 (n 48) sections 14-16.

${ }^{144}$ Canada Oceans Act 1996 (n 44) section 23.

${ }^{145}$ House/Senate Bill (n 12) sections 13(4) and (5).

${ }^{146}$ LOS Convention (n 1) arts 68 and 77(4).

${ }^{147}$ House/Senate Bill (n 12) sections 14(1) and 23.

148 Sea Fisheries Act 1971, Cap 404, amended as Act No 71 of 1992, Cap S4 LFN 2004. In section 15 of the 1992 amendment, 'fish' is defined to refer to 'any aquatic creature whether fish or not and includes shell-fish, crustaceans, turtles and aquatic mammals.' The Act is at <http://www.placng.org/lawsofnigeria/files/S4.pdf>.

${ }^{149}$ LOS Convention (n 1) art 56(1)(b)(i).

${ }^{150}$ House/Senate Bill (n 12) section 10(1)(b)(i).

151 Ibid., section 14(4).

152 Ibid., section 18.

${ }^{153}$ Constitution of the Federal Republic of Nigeria 1999 (n 13) art 251(1)(g).

${ }^{154}$ House/Senate Bill (n 12) section 15.

155 Canada Oceans Act 1996 (n 44) sections 9 and 20-21.

156 South Africa Maritime Zones Act 1994 (n 46) sections 3(2), 4(2) and 9(1).

${ }^{157}$ House/Senate Bill (n 12) sections 4-5 (territorial sea); section 8 (contiguous zone and jurisdiction regarding archaeological and historical objects); section 12 (Exclusive Economic Zone).

158 Ibid., section 15(2).

159 Ibid., section 16.

${ }^{160}$ Canada Oceans Act 1996 (n 44) sections 23(1), 25 and 26.

${ }^{161}$ House/Senate Bill (n 12) sections 6(5) and 16(2).

162 Ibid., sections 1(4) - (5) and 13(4) - (5), on delineating bay closing lines and charts depicting territorial sea baselines and the outer limits of the continental shelf, and their notification to the UN; sections 6(2) and 7(2) - (3), regarding enforcement of laws applying to the contiguous zone, and as to preventing trafficking in archaeological and historical objects found within that zone; sections 11(3)-(4) and (6) - (7) on the construction, publicity, operation, use and removal of artificial islands, installations and structures in the Exclusive Economic Zone.

${ }^{163}$ Canada Oceans Act 1996 (n 44) sections 25-26 and 52.1.

${ }^{164}$ House/Senate Bill (n 12) section 19.

165 Belize Maritime Areas Act 1992 (n 48) section 25.

166 Kenya Maritime Zones Act 1989 (n 51) section 13(1); South Africa Maritime Zones Act 1994 (n 46) sections $15(2)-(4)$.

${ }^{167}$ For example, Ghana Maritime Zones Delimitation Law 1986 (n 49) section 9; Bahamas Archipelagic Waters and Maritime Jurisdiction Act 1993 (n 47) section 18.

${ }^{168}$ South Africa Maritime Zones Act 1994 (n 46) section 15(1) and Schedule 1; Namibia Territorial Sea and EEZ Act 1990 (n 52) section 7 and Schedule. The Schedules of both detail the legislations repealed and amended and the extent of the required amendments.

169 Sections 54 and 55 of the Canada Oceans Act 1996 (n 44) identify specific legislations repealed by it. Sections 56-108 identify all legislations affected by the Act and set out their required amendments.

${ }^{170}$ Jamaica EEZ Act 1991 (n 56) section 22 and Schedule, Appendix and Memorandum. When it adopted the Maritime Areas Act, 1996 (n 56) with a focus on internal and archipelagic waters, the territorial sea and the contiguous zone, it only identifies in section 29 the laws that are repealed by it.

${ }^{171}$ New Zealand Territorial Sea and EEZ Act 1977 (n 50) section 33.

172 House/Senate Bill (n 12) section 20. The section repeals the Territorial Waters Act 1967, and the Exclusive Economic Zone Act 1978 (n 35 and n 36 respectively).

${ }^{173}$ House/Senate Bill (n 12) sections 21 and 22. For some of the legislation identified as subject to consequential amendments, see notes 104-107 above with accompanying text.

${ }^{174}$ Some examples are the Bahamas Archipelagic Waters and Maritime Jurisdiction Act 1993 (n 47) section 2; Belize Maritime Areas Act 1992 (n 48) section 2; Jamaica Maritime Areas Act 1996 (n 56) section 2; Kenya Maritime Zones Act 1989 (n 51) section 2; South Africa Maritime Zones Act 1994 (n 46) section 1; Tanzania Territorial Sea and EEZ Act 1989 (n 53) section 2.

${ }^{175}$ Ghana Maritime Zones Delimitation Law 1986 (n 49) passim; Cyprus Exclusive Economic Zone Law 2004 (n 55) sections 2(1) and (2).

176 See definition of 'Namibia' in the Namibia Territorial Sea and EEZ Act (n 52) section 1. Geographical Namibia is identified in art 1(4), Constitution of the Republic of Namibia < http://www.orusovo.com/namcon/NamCon.pdf>. 
177 Jamaica Maritime Areas Act 1996 (n 56) section 2, where 'Jamaica' is defined to refer to its geographical territory as identified in the Jamaica Independence Act 1962, section 4(1) <http://moj.gov.jm/sites/default/files/laws/Jamaica\%20Independence\%20Act,\%201962.pdf>. The definition of 'Republic' in Cyprus' Contiguous Zone Law 2004, and its Exclusive Economic Zone Law 2004 (n 55) section 2 respectively, of both legislations, is the 'Republic of Cyprus.' The latter is identified by its geographical territory in the Constitution of the Republic of Cyprus, Appendix A, art $1<\mathrm{http}: / /$ www.kypros.org/Constitution/English/>.

${ }^{178}$ Canada Oceans Act 1996 (n 44) sections 4-8, 15 and 19; India Territorial Waters, Continental Shelf, Exclusive Economic Zone and Other Maritime Zones Act 1976 (n 45) section 2; Kenya Maritime Zones Act 1989 (n 51) sections 3(1) - (3) and First Schedule.

${ }^{179}$ See discussion at Section 4.3 explaining the legal uncertainty this has created.

${ }^{180}$ House/Senate Bill (n 12) section 23.

${ }^{181}$ Ibid., section 24.

${ }^{182}$ See Section 3.2.

${ }^{183}$ See earlier discussions in Sections 2.1, 4.1, 4.3 and 4.8.

${ }^{184}$ See notes 13 and 61 with accompanying texts.

${ }^{185}$ Perusal of the national legislations of African coastal states relevant to implementation of the LOS Convention held by the United Nations Department of Oceans and the Law of the Sea discloses that though they are parties to the Convention, many have not appropriately reflected the claims and jurisdictions allowed under the Convention: <http://www.un.org/depts/los/LEGISLATIONANDTREATIES/africa.htm〉.

${ }^{186}$ For detailed discussion, see D.M. Dzidzornu, Ocean policy in Africa and treaty aspects of marine fisheries exploitation, management and environmental protection, in: A. Chircop et. al. (Eds.), Ocean Yearbook, Volume 25, Brill/Nijhoff, 2011, pp. 27-100, at 51-79 and 94-97.

${ }^{187}$ Report of the Eleventh Meeting of the Contracting Parties to the Convention for Cooperation in the Protection, Management and Development of the Marine and Coastal Environment of the Atlantic Coast of the West, Central and Southern African Region, Cape Town, South Africa, 17-21 March 2014, UNEP(DEPI)/WACAF/COP.11/9/Rev.1, 21 March 2014 [henceforth Abidjan COP 11], Decision CP 11/4: Ocean Governance; and Annex II: Cape Town Declaration, at Preamble paras 2 and $4-11$, Resolutions $1-3$ and $8-12$.

${ }^{188}$ See Cape Town Declaration, (n 187) Resolution 7, and Abidjan COP 11 (n 187), Draft Terms of Reference of the Regional Coordination Centre and Selection Criteria, UNEP(DEPI)/WACAF/COP.11/Inf.6.

${ }^{189}$ See notes 129-131 above, with accompanying text.

${ }^{190}$ See Economic Community of West African States, ECOWAS Environmental Policy (Environmental Directorate, ECOWAS Commission, Abuja, Nigeria 2008) pp. 1-28, at sections 2.4, 5.1, 5.3, 5.4 subsection 2.4, and section 6.1 〈http://www.comm.ecowas.int/dept/d/d2/en/ecowas_environment_policy.pdf >.

${ }^{191}$ Thirty-Fifth Ordinary Session of the Authority of Heads of State and Government, Abuja, Supplementary Act A/SA.4/12/08 Relating to the ECOWAS Environmental Policy, published and in force 19 December 2008, arts 10 and 12. The Act is available in one document with the Policy at the source cited at $n 190,29-39$.

${ }^{192}$ Ibid., arts 20(1) and (2).

${ }^{193}$ See information online <http://parl.ecowas.int/comm_agric.html>.

${ }^{194}$ See AMCEN/AU/UNEP, United Nations Conference on Sustainable Development outcomes and their implications for Africa, African Ministerial Conference on the Environment, Fourteenth Session, Ministerial Segment, AMCEN/14/3 (Arusha, Tanzania, 12-14 September 2012) paras 27-32 and 35(a); African Union, 2050 Africa's Integrated Maritime Strategy, <http://pages.au.int/maritime>; Cape Town Declaration (n 187). 